Usman Ali Iftikhar, Mikkel Kallesoe, Anantha Duraiappah, Gaya Sriskanthan, Susan V. Poats and Brent Swallow

Exploring the inter-linkages among and between Compensation and Rewards for Ecosystem Services (CRES)
and human well-being 



\section{Exploring the inter-linkages among and between Compensation and Rewards for Ecosystem Services (CRES) and human well-being}

Usman Ali Iftikhar, Mikkel Kallesoe, Anantha Duraiappah, Gaya Sriskanthan, Susan V. Poats and Brent Swallow 


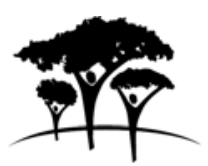

World Agroforestry Centre

TRANSFORMING LIVES AND LANDSCAPES

Correct citation: Iftikhar UA, Kallesoe M, Duraiappah A, Sriskanthan G, Poats SV and Swallow B. 2007. Exploring the inter-linkages among and between Compensation and Rewards for Ecosystem Services (CRES) and human well-being: CES Scoping Study Issue Paper no. 1. ICRAF Working Paper no. 36. Nairobi: World Agroforestry Centre.

Titles in the Working Paper Series aim to disseminate interim results on agroforestry research and practices and stimulate feedback from the scientific community. Other publication series from the World Agroforestry Centre include: Agroforestry Perspectives, Technical Manuals and Occasional Papers.

Published by the World Agroforestry Centre

United Nations Avenue

PO Box 30677, GPO 00100

Nairobi, Kenya

Tel: +254(0)20 7224000, via USA +1 6508336645

Fax: +254(0)20 7224001, via USA +1 6508336646

Internet: www.worldagroforestry.org

Contact Brent Swallow: B.Swallow@,cgiar.org

(C) World Agroforestry Centre 2007

Working Paper no. 36

The views expressed in this publication are those of the author(s) and not necessarily those of the World Agroforestry Centre and co-publishers.

Articles appearing in this publication may be quoted or reproduced without charge, provided the source is acknowledged.

All images remain the sole property of their source and may not be used for any purpose without written permission of the source.

With generous support of the International Development Research Centre, Canada

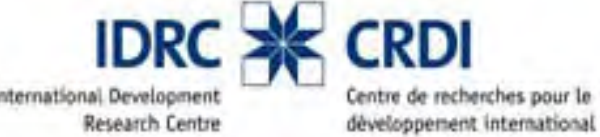


The World Agroforestry Centre (ICRAF) and a diverse team of partners were tasked by the International Development Research Centre (IDRC) to contribute to the conceptualization and development of their Rural Poverty and Environment (RPE) programme related to Compensation and Rewards for Environmental Services (CRES) by providing an overview of relevant developments in Africa, Asia and Latin America, a global synthesis of results and recommendations. Truly global in nature, the CRES Scoping Study was undertaken by the following partners and collaborators based in 7 countries across 4 continents.

The African Centre for Technology Studies (ACTS) is a Nairobi-based science, technology and environment policy Inter-governmental organization (IGO) that generates and disseminates new knowledge through policy analysis and outreach. The Centre's mission is to strengthen the capacity of African countries and institutions to harness science and technology for sustainable development. ACTS strives to rationalize scientific and technological information to enable African countries make effective policy choices for improved living standards. ACTS works with partners and networks including academic and research institutions, national governments, UN bodies, regional and international processes and NGOs. ACTS' research and capacity building activities are organized in five programmatic areas: Biodiversity and Environmental Governance; Energy and Water Security; Agriculture and Food Security; Human Health; and Science and Technology Literacy. Its members are: Kenya, Malawi, Malta, Uganda and Ghana, The World Agroforestry Centre (ICRAF) and the Third World Academy of Sciences (TWAS) are founding members of ACTS.

www.acts.or.ke

Corporación Grupo Randi Randi (CGRR) is a non-profit corporation, whose mission is to build and motivate equitable development and a healthy environment, stimulating the imagination, creativity and the talent of our collaborators, incorporating gender, generation and ethnic equality, local participation, the sustainable management of natural resources and the conservation of biodiversity. CGRR was legalized in Ecuador in 2000, currently has 17 members, and operates a range of research and development projects, with international and national funding, ranging from participatory watershed management, watershed inventories and modeling, gender and environment, community conservation, conservation planning for protected areas and integrated crop management for sustainable development. CGRR is a member of the Consorcio para el Desarrollo Sostenible en los Andes (CONDESAN), the International Union for the Conservation of Nature (IUCN), the Ecuadorian association of environmental NGOs, (CEDENMA), and is a founding member of RISAS, a national network focused on the study and promotion of environmental services research and action. www.randirandi.org

Forest Trends is an international non-profit organization that works to expand the value of forests to society; to promote sustainable forest management and conservation by creating and capturing market values for ecosystem services; to support innovative projects and companies that are developing these new markets; and to enhance the livelihoods of local communities living in and around those forests. We analyze strategic market and policy issues, catalyze connections between forward-looking producers, communities and investors, and develop new financial tools to help markets work for conservation and people.

www.forest-trends.org

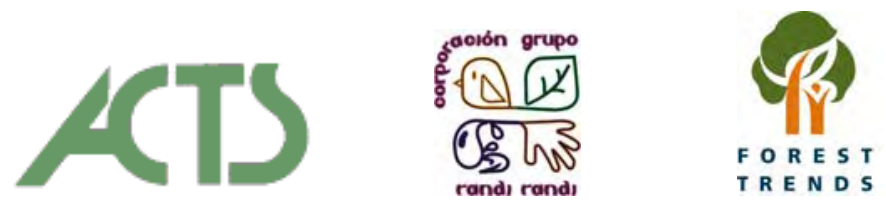


The Institute for Social and Economic Change (ISEC) is an all India Institute for Interdisciplinary Research and Training in the Social Sciences, established in 1972 by the late Professor VKRV Rao. It is registered as a Society under the Karnataka Societies Registration Act, 1960, to create a blend of field-oriented empirical research and advances in social science theories leading to better public policy formulation. Its mission is to conduct interdisciplinary research in analytical and applied areas of social sciences, encompassing diverse aspects of development; to assist both central and state governments by undertaking systematic studies of resource potential, identifying factors influencing growth and examining measures for reducing poverty; and to establish fruitful contacts with other institutions and scholars engaged in social science research through collaborative research programmes and seminars, and to conduct training courses and refresher programmes for university and college teachers and public functionaries.

www.isec.ac.in

The World Conservation Union (IUCN): Founded in 1948, IUCN brings together States, Government agencies and a diverse range of NGOs in a unique partnership with over 1000 members spread across some 150 countries. As a Union IUCN seeks to influence, encourage and assist societies throughout the world to conserve the integrity and diversity of nature and to ensure that any use of natural resources is equitable and ecologically sustainable.

www.iucn.org

UNEP is the voice for the environment in the United Nations system. It is an advocate, educator, catalyst and facilitator, promoting the wise use of the planet's natural assets for sustainable development. UNEP's mission is "to provide leadership and encourage partnership in caring for the environment by inspiring, informing, and enabling nations and peoples to improve their quality of life without compromising that of future generations".

www.unep.org

The World Agroforestry Centre (ICRAF) is the international leader in the science and practice of integrating 'working trees' on small farms and in rural landscapes. We have invigorated the ancient practice of growing trees on farms, using innovative science for development to transform lives and landscapes. The World Agroforestry Centre is one of the 15 centres supported by the Consultative Group on International Agricultural Research (CGIAR).

http://www.worldagroforestry.org
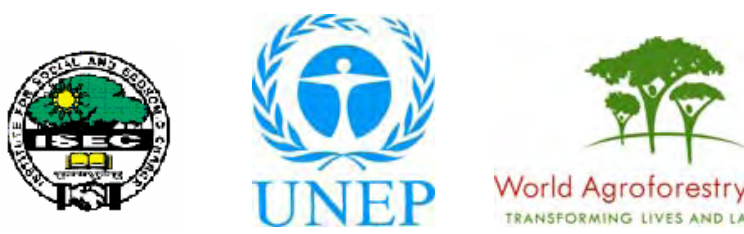

World Agroforestry Centre

TRANSFORMUNG LIYES AND IANDSCAPES 


\section{About the authors}

Usman Iftikhar

Mikkel Kallesoe

Anantha Duraiappah

Gaya Sriskanthan

Susan Poats

Brent Swallow
Environmental Economist, Coordinator, Asia Regional Environmental Economics Programme, World Conservation Union (IUCN), Colombo, Sri Lanka.

Contact: uai@iucnsl.org

Senior Programme Officer, Asia Regional Environmental Economics Programme, World Conservation Union (IUCN), Colombo, Sri Lanka.

Chief, Analysis and Emerging Issues Unit, Division of Environmental Law and Conventions (DELC), United Nations Environment Programme (UNEP) Nairobi, Kenya.

Asia Regional Species Conservation Programme, World Conservation Union (IUCN), Colombo, Sri Lanka.

Anthropologist with a strong commitment to conservation and sustainable development. She is a founding member of Corporación Grupo Randi Randi (CGRR), Quito, an Ecuadorian non-profit organization.

Principal Scientist and Theme Leader for Environmental Services, World Agroforestry Centre (ICRAF) Nairobi, Kenya. Overall Coordinator of the CES Global Scoping Study. 


\begin{abstract}
This paper is the fifth in a series of nine interlinked papers commissioned by the Rural Poverty and Environment Programme (RPE) of the International Development Research Centre (IDRC) as part of a research project entitled scoping study of compensation for ecosystem services. The purpose of this project is to provide the RPE with a broader and richer deliberation on the potential for economic instruments (including market, financial and incentive-based instruments), which conserve ecosystem services and at the same time contribute to poverty reduction in the developing world.

This paper is prepared by IUCN - The World Conservation Union, The United Nations Environment Programme (UNEP), Forest Trends, Corporacion Grupo Randi Randi (CGRR), and the World Agroforestry Centre (ICRAF). The purpose of this paper is to develop in-depth understanding of the interface between Compensation and Rewards for Ecosystem Services (CRES) and human well-being, namely how, where and when CRES options are relevant to poverty reduction and the well-being of the poor. CRES in the context of this paper is being explored as: compensation for ecosystem services (CES) in monetary or non-monetary payments made by those whose actions modify ecosystem services in a way that is perceived to be harmful to the ecosystem and thus its services (the proverbial polluters pay principle); and rewards for ecosystem services (RES) in monetary or non-monetary payments made to those whose actions modify ecosystem services in exchange for undertaking good stewardship or guardianship of the ecosystem (the beneficiaries pay principle).

This paper explores the relationship between CRES and poverty reduction and the well-being of the poor through the Millennium Ecosystem Assessment (MA) framework. The MA framework has been instrumental in examining and revealing the inter-linkages, synergies and trade-offs between (and among) ecosystem services, and between ecosystem services and human well-being. The framework provides a unique pathway to understanding CRES's potential ability to reduce poverty by considering where synergies are possible and where trade-offs are inevitable. This framework has important implications for an approach that pursues conservation and poverty reduction jointly.
\end{abstract}

\title{
Keywords
}

Environmental services, conservation, compensation and reward mechanisms, ecosystem services, poverty reduction, human well-being.

\section{Acknowledgements}

This paper represents a fusion of ideas among many representatives who attended the project regional workshops, (co)authors of this and other issue papers and other people not associated with this project. We are grateful to all the people for enriching this paper through their contributions. We also acknowledge the generous financial and intellectual support of IDRC, particularly Dr. Hein Mallee. 


\section{Preface}

From the beginning of 2006 until March 2007, the World Agroforestry Centre (ICRAF) led a consortium of organizations and individuals from around the world in a pan-tropical scoping study of Compensation and Rewards for Environmental Services (CRES). The scoping study was commissioned by the Rural Poverty and Environment Programme of the International Development Research Centre of Canada (IDRC) to identify critical issues affecting the development, operation, impacts and institutionalization of mechanisms linking beneficiaries of ecosystem services with stewards of those ecosystems. Particular attention is paid to the potential for CRES to alleviate or exacerbate the multiple dimensions of poverty: rights to productive assets, streams of income and consumption, and vulnerability to shocks.

The scoping study included a series of regional workshops held in Latin America (Quito, Ecuador), Asia (Bangalore, India) and Africa (Nairobi, Kenya). Participants presented and discussed practical CRES experiences from across the developing world, experiences which informed and challenged the development of several cross-cutting issue papers. A series of nine working papers have been prepared to summarize the results of the scoping study, including an introductory paper, three regional workshop reports, and five issue papers on key topics.

ICRAF Working paper 32 - Compensation and Rewards for Environmental Services in the Developing World: Framing Pan-Tropical Analysis and Comparison.

ICRAF Working paper 33 - Report on the Latin American Regional Workshop on Compensation for Environmental Services and Poverty Alleviation in Latin America.

ICRAF Working paper 34 - Asia Regional Workshop on Compensation for Ecosystems Services. A component of the global scoping study on compensation for ecosystem services.

ICRAF Working paper 35 - African Regional Workshop on Compensation for Ecosystem Services (CES).

ICRAF Working paper 36 - Exploring the inter-linkages among and between Compensation and Rewards for Ecosystem Services (CRES) and human well-being: CES Scoping Study Issue Paper no. 1.

ICRAF Working paper 37 - Criteria and indicators for environmental service compensation and reward mechanisms: realistic, voluntary, conditional and pro-poor: CES Scoping Study Issue Paper no. 2.

ICRAF Working paper 38 - The conditions for effective mechanisms of Compensation and Reward for Environmental Services (CRES): CES Scoping Study Issue Paper no. 3.

ICRAF Working paper 39 - Organization and governance for fostering pro-poor Compensation for Environmental Services: CES Scoping Study Issue Paper no. 4.

ICRAF Working paper 40 - How important will different types of Compensation and Reward Mechanisms be in shaping poverty \& ecosystem services across Africa, Asia \& Latin America over the next two decades? CES Scoping Study Issue Paper no. 5.

The working papers are designed for relatively limited circulation of preliminary material. We anticipate that all of the papers will be revised and published in a formal outlet within the next year.

Brent Swallow

World Agroforestry Centre

Nairobi, Kenya
Hein Mallee

International Development Research Centre

Singapore 


\section{Contents}

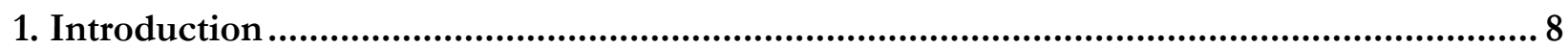

2. Ecosystem Services, Poverty and Human Well-Being …................................................11

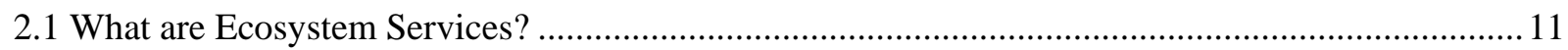

2.2 Why ecosystems, and ecosystem services, deteriorate .................................................................... 13

2.3 What is Poverty and Human Well-Being, and what are the causes and manifestations? .................15

3. Ecosystem Services and Human Well-Being: Inter-Linkages, Synergies \& Trade-Offs....21

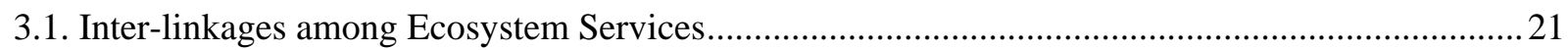

3.2. Inter-Linkages among Constituents and Determinants of Human well-being..................................22

3.3. Inter-Linkages across Ecosystem Services and Constituents of Well-Being...................................23

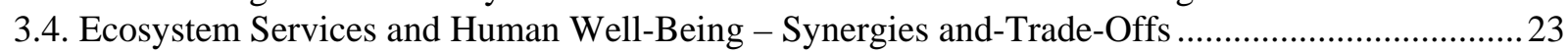

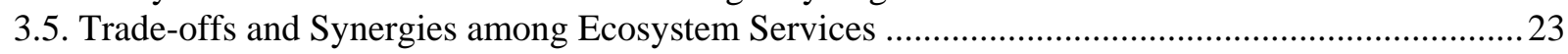

3.6. Trade-offs and Synergies between the Present and the Future ......................................................2 24

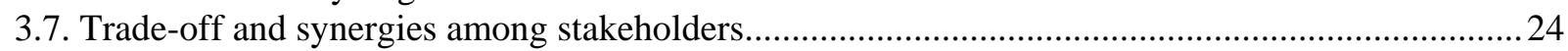

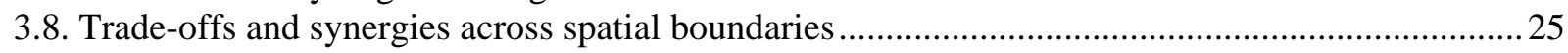

4. Status of Rewards and CES \& Poverty Reduction - Experiences to date.......................... 26

4.1. Status of CES \& Poverty Reduction - Experiences to date...........................................................29

5. Findings: What is the relevance of CRES to poverty reduction and human well-being? .. 30

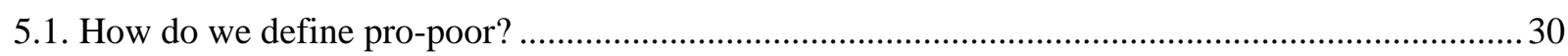

5.2. Is CRES relevant to Poverty Reduction and Human Well-Being? When? How? ............................... 30

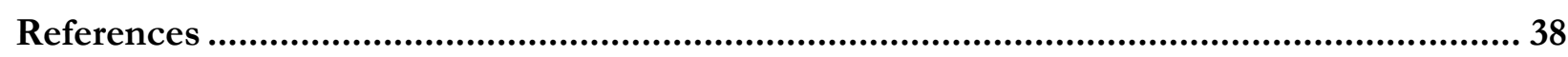

Annex 1. Indicative list of ecosystem services.................................... 40 


\section{Introduction}

This paper is the fifth in a series of nine interlinked issue papers commissioned by the Rural Poverty and Environment Programme (RPE) of the International Development Research Centre (IDRC) as part of a research project entitled scoping study of compensation for ecosystem services. The purpose of this project is to provide the RPE with a broader and richer deliberation on the potential for economic instruments (including market, financial and incentive-based instruments), which conserve ${ }^{1}$ ecosystem services and at the same time contribute to poverty reduction in the developing world.

RPE has raised important questions about the impact and future prospects of compensation and payments for ecosystem services, and their potential role in helping to make these instruments more beneficial to the poor in the rural landscapes of the developing world. These questions are reflective of the growing awareness that ecosystems continue to be undervalued - despite their enormous importance for human well-being - and the loss and decline of ecosystem services continue unabated despite the application of conservation approaches such as protected areas, integrated conservation and development and community-based natural resource management. The traditional exclusionary approach of protected areas, for example, have for the most part not produced desired conservation outcomes, because they have often impacted negatively on the livelihoods of local communities through reducing the land and resource use options open to them. Especially in situations where the incidence of poverty is high (as is the case in many developing countries), the communities who manage and use ecosystems have proved to be unwilling and frequently economically unable, to tolerate the high opportunity costs incurred by protectionist approaches to conservation.

While integrated conservation and development and community-based natural resource management approaches in a few cases have shown more positive results in ecosystem conservation and poverty terms, they have often been difficult to sustain in financial terms. Depending for the most part on relatively short-term injections of donor funding and central government subventions, the limited budgets available to national conservation authorities have rarely been sufficient to provide the relatively high levels of long-term funding or technical assistance that these approaches demand. As a consequence, positive results with respect to ecosystem management and poverty, often over the longterm, are set back.

At the heart of the above questions is the growing awareness of the linkages between poverty and the environment, namely that poverty is multidimensional and ecosystems play a vital role through the provision of essential services, which provide the poor with alternatives to either escape poverty or avert its worst effects. For example, ecosystem regulating services like water regulation and purification contribute directly to the health of the poor, while provisioning services like non-timber forest products contribute to their material wealth. Inadequate access to, and loss and decline of ecosystem services, often exacerbates poverty. Empirical evidence of the links between poverty and the environment reveal that socially disadvantaged and vulnerable people in the developing world, particularly women, tend to suffer disproportionately when ecosystem services decline.

In this context, payments for ecosystem services has arisen as a new direct conservation approach, explicitly recognizing the need to bridge the interests of those who influence the provision of ecosystem services with those who depend on them directly for their well-being. These interests can be reconciled by payments from the beneficiaries to the providers, providing both an incentive as well as the financial resources needed to sustain ecosystem conservation. Compensation, on the other hand, is paid to those who are adversely affected (incur damages) by the loss and decline of ecosystem services

\footnotetext{
${ }^{1}$ Conservation includes sustainable use of natural resources
} 
by those whose actions lead to that decline. These similarly raise financial resources, help to change the pattern of existing incentives to degrade ecosystems, and over time contribute to ecosystem conservation. While compensation and payments for ecosystem services hold much promise for ecosystem conservation and financial sustainability, deciphering their role in poverty reduction holds both potential promise and challenges. For example, it is often recognized that poor people are the main providers of many ecosystem services and are most adversely impacted by degradation - they are often not in a position to access and benefit from these schemes because of their social, economic and political positions.

In light of this, a diverse group of organizations ${ }^{2}$ has been formed to undertake research on a wide range of issues related to the conceptualization, design and implementation of compensation and payment mechanisms. Specifically, the project hypothesizes that there is greater scope in Africa, Asia and Latin America for:

- Using ecological assessment and economic valuation to better integrate ecosystem services into poverty reduction and sustainable development planning;

- Devising processes of scoping, negotiating and enforcing agreements over ecosystem services that improve the negotiating power and bargaining position of otherwise disadvantaged groups;

- Instituting pro-poor ecosystem service compensation or payment schemes to the advantage of those who benefit from ecosystem services and those who generate those services.

The broad objective of the scoping study is to contribute to the conceptualization and development of RPE programming related to Compensation for Ecosystem Services by providing an overview of relevant developments in Africa, Asia and Latin America, a global synthesis of the results, and recommendations for a possible niche for RPE programming. The specific objectives of the scoping study include:

1. Review and synthesize information on recent development, current status, and likely future development of mechanisms of compensation for ecosystem services in Latin America, Africa and Asia;

2. Review evidence, solicit stakeholder perceptions, and identify knowledge gaps related to key issues affecting the potential for mechanisms of compensation for ecosystem services to alleviate rural poverty and conserve ecosystem function in Latin America, Africa and Asia; and

3. Identify and discuss a set of knowledge gaps, policy issues, and research questions that link compensation for ecosystem services with the RPE focal areas of environmental governance, access and rights to natural resources, community integration with wider socio-economic systems, and adaptive learning in key hotspots of rural poverty and environmental degradation. In particular, suggest ways in which RPE might support research on these issues by Southern researchers.

The present paper is prepared by IUCN - The World Conservation Union, The United Nations Environment Programme, Forest Trends, Corporacion Grupo Randi Randi, and the World Agroforestry Centre (ICRAF). The purpose of this paper is to develop in-depth understanding of the interface between Compensation and Reward ${ }^{3}$ for Ecosystem Services (CRES) and human well-being,

\footnotetext{
2 The consortium is led by the World Agroforestry Centre (ICRAF), through its offices in Nairobi, Kenya and Bogor, Indonesia. Other members in the consortium include the World Conservation Union (especially its offices in Gland, Switzerland and Colombo, Sri Lanka), Forest Trends in Washington DC, USA (also representing the Resources and Rights Initiative and Ecoagriculture Partners which are also based in Washington DC), Corporacion Grupo Randi Randi in Quito, Ecuador, the African Centre for Technology Studies in Nairobi, Kenya, the Institute for Social and Economic Change in Bangalore, India, and the United Nations Environment Programme in Nairobi, Kenya.

${ }^{3}$ We have chosen the term "rewards" to reflect the monetary and non-monetary nature of payments.
} 
namely how, where and when CRES options are relevant to poverty reduction and the well-being of the poor. CRES in the context of this paper is being explored as: compensation for ecosystem services (CES) in monetary or non-monetary payments made by those whose actions modify ecosystem services in a way that is perceived to be harmful to the ecosystem and thus its services (the proverbial polluters pay principle); and rewards for ecosystem services (RES) in monetary or non-monetary payments made to those whose actions modify ecosystem services in exchange for undertaking good stewardship or guardianship of the ecosystem (the beneficiaries pay principle).

This paper explores the relationship between CRES and poverty reduction and the well-being of the poor through the Millennium Ecosystem Assessment (MA) framework. The MA framework has been instrumental in examining and revealing the inter-linkages between (and among) ecosystem services, and between ecosystem services and human well-being. The framework provides an appropriate conceptual framework for understanding the potential for CRES mechanisms to reduce poverty by considering where synergies are possible and where trade-offs are inevitable. This framework has important implications for an approach that pursues conservation and poverty reduction jointly.

In terms of organization of this paper, the next section outlines the varied array of ecosystem services and the constituents of human well-being (based on the MA framework). Section three then illustrates direct and indirect inter-linkages between and among ecosystem services and human well-being, and identifies potential synergies and trade-offs that form the basis for assessing linkages and relationship with CRES. In section four experiences to date on CRES is presented. And finally section five presents the findings on the relevance and relationship between CRES and poverty reduction and human wellbeing.

The methodology for this paper is based on review of literature and publications on Payments for Environmental Services, the Millennium Ecosystem Assessment and poverty frameworks, lessons drawn from the regional workshops held, and a writing workshop held in Kenya. 


\section{Ecosystem Services, Poverty and Human Well-Being}

This section sets the basis for developing the conceptual framework to examine the inter-linkages, synergies and trade-offs between ecosystem services and the well-being of the poor. In this section, we define and examine in detail the elements separately using the Millennium Environmental Assessment Framework (see figure 1 below). The overview of ecosystem services below is meant to clarify the fundamental terminology and concepts so as to provide a conceptual basis for understanding how ecosystem services benefit people, and in particular the poor. A brief exploration of trends in ecosystem health, and the implications of this for the well-being of the poor is also provided below. In the last sub-section, the evolving understanding of poverty is discussed in its multidimensionality, and key constituents and determinants are deciphered.

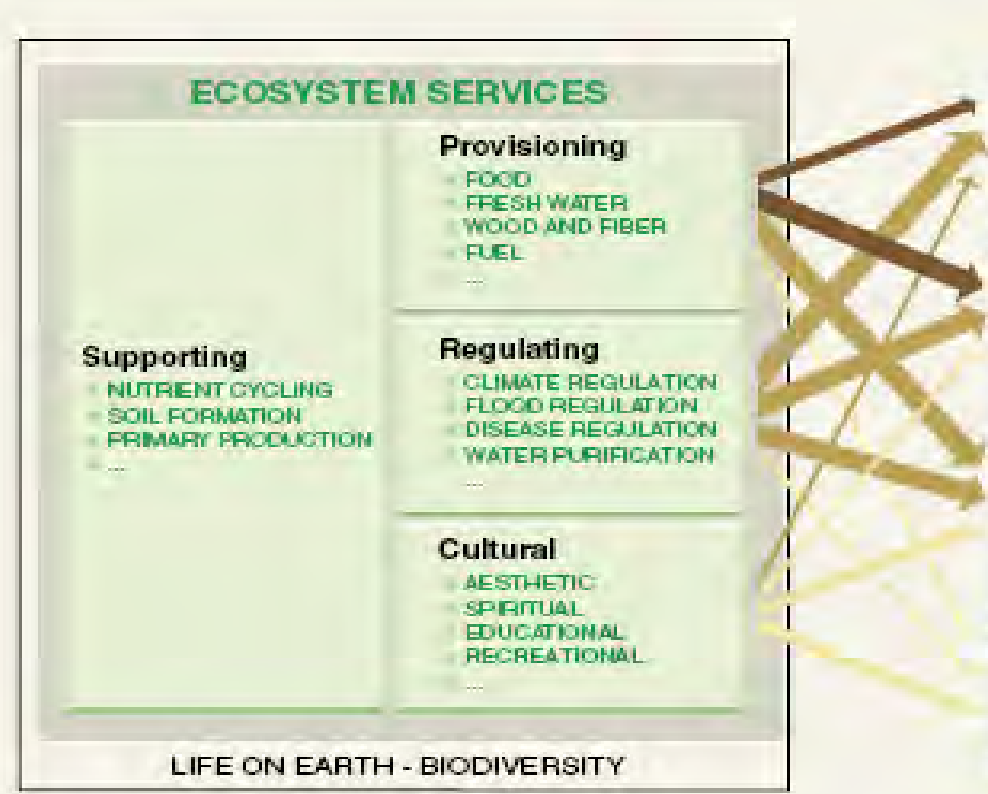

ARROYIS COLOR

Potential for mediation by

socioeconomic factors

Low

Madium

High

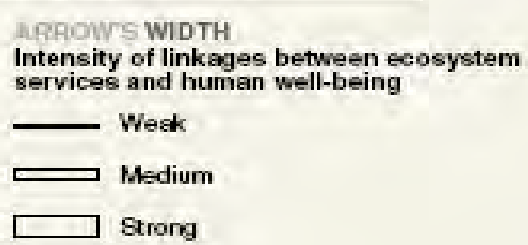

MRAONYS WIDTH

Intensity of linkages between ecosystem

- Weak

Strong

\section{CONSTITUENTS OF WELL-BEING}

\section{Security}

PERSOMAL SAFETY

SECURE RESOUACE ACCESS

SECURITY FROM DISASTERS

\section{Basic material}

for good life

ADEOUATELAELHHOODS

of choice

SUFFICIENT MUTAITIOUS FOOD

TELTER

ACCESS TO GOODS

\section{Health} and action

STRENIGTH PPOATUNITY TO BE ABLE TO ACHIEVE

FEELING WELL VALUES DOING

ACCESS TOCLEAN AIP

AHD WATER

Good social relations

SOCIAL OOHESION

MUTUAL AESPECT

ABLITY TO HELP OTHERS

Figure 1: The Millennium Environmental Assessment Framework

\subsection{What are Ecosystem Services?}

The Millennium Ecosystem Assessment (MA) defines ecosystems as dynamic complexes of plant, animal and micro-organism communities and their nonliving environment interacting as functional units (2003). The scale and boundaries of this 'functional unit' can vary according to perspective and there can be innumerable types of ecosystems on a spectrum of spatial scales: from a log to a forest. The term ecosystem is useful in describing the significance of interactions between the biotic (living) and abiotic (non-living) environment within a given area. Though it is accepted that one ecosystem can overlap and interact with another, the definition implies that intra-ecosystemic interactions are stronger than inter-ecosystemic interactions. This description lends clarity to the nature and scale of ecological relationships, but does not allow for typological categorization of natural systems. The MA analyses of ecosystems use the concept of 'biomes' as the basis for categorizing different types of natural systems. Biomes can be broadly differentiated by distinctive features such as a characteristic complement of species, representative habitats and vegetation types, and location with regards to geography, climatic 
and altitudinal zones. The term allows one to conceptually differentiate between larger ecosystem types that fall into ecologically meaningful and distinct classes (MA 2005). In the context of ecosystem services the classification system of biomes is a useful tool that permits us to compartmentalize ecosystem types and understand the distinctive ecological services they provide.

Though the process of categorizing biomes comes with its own interpretive difficulties, there have been a number of attempts to identify representative biomes. The MA draws upon the 14 terrestrial biomes identified by the World Wide Fund for Nature (WWF) and complements these with a range of broader biome categories (see Table 1).

As described above, ecosystems are complex systems devised of a multitude of components and interactions that provide ecosystem services. The MA defines ecosystem services as the benefits ecosystems provide for human well-being (MA 2003). Based on this definition, four main classes of ecosystem services can be identified. These are the provisioning, regulating, supporting and cultural services. These services manifest in a variety of forms, from concrete harvestable goods such as timber, fish and water to more abstract regulating services such as pollination of crops, flow regulation for flood control and maintenance of biodiversity. There are several different ways of categorizing ecosystems services, specifically, services can be grouped organizationally, separating services in relation to species or biotic entities; descriptively, identifying different categories of services, such as renewable or non-renewable, biotic or biogeochemical; or functionally in terms of the types of services provided, such as provisioning or regulating services (MA 2003). For the purpose of consistency, this paper refers to ecosystem services with respect to their functional groups, as adopted by both the Convention on Biological Diversity and the MA. Annex 1 provides an overview of the main types of ecosystem services as identified by the CBD under the broad categories of provisioning services, regulating services, cultural services, and supporting services identified by the MA.

\section{Table 1: Biome classifications used in the Millennium Ecosystem Assessment}

\section{Terrestrial biomes as identified by WWF}

$1=$ Tropical \& Subtropical Moist Broadleaf Forests

$2=$ Tropical \& Subtropical Dry Broadleaf Forests

$3=$ Tropical \& Subtropical Coniferous Forests

$4=$ Temperate Broadleaf $\&$ Mixed Forests

$5=$ Temperate Conifer Forests

$6=$ Boreal Forests/Taiga

7 = Tropical \& Subtropical Grasslands, Savannas \&

Shrublands

$8=$ Temperate Grasslands, Savannas \& Shrublands

$9=$ Flooded Grasslands \& Savannas

$10=$ Montane Grasslands \& Shrublands

$11=$ Tundra

$12=$ Mediterranean Forests, Woodlands \& Scrub

$13=$ Deserts \& Xeric Shrublands

$14=$ Mangroves

\section{Broader biome classifications by MA}

\begin{tabular}{|l|l|}
\hline \multirow{3}{*}{ Forest } & - Boreal \\
& - Temperate \\
& - Tropical \\
\hline \multirow{5}{*}{ Dryland } & - Temperate grassland \\
& - Mediterranean \\
& - Tropical grassland and savannas \\
& - Desert \\
\hline
\end{tabular}

Inland water

Coastal

Marine

Island

Mountain

Polar

*WWF website http://www.worldwildlife.org/science/data/attributes.cfm; MA (2005)

More precisely, provisioning services cover natural resources and products derived from ecosystems, and represent the flow of goods. Regulating or supporting services are the actual life-support functions ecosystems provide and are normally determined by the size and quality (the stock) of the ecosystem. 
Cultural services refer to the non-material benefits obtained from ecosystem services such as spiritual and religious significance.

\subsection{Why ecosystems, and ecosystem services, deteriorate}

As illustrated in Figure 2 below, ecosystem services are not only of direct value to humans through provisioning services, they offer indirect benefits through sustaining life support systems and by supporting and promoting the natural resource base upon which economic activities are founded. Moreover ecosystems are a source of tremendous existence values (such as cultural, religious and spiritual) regardless of their use, as well as option values - signifying the future direct, indirect and existence values flowing from these resources. Yet despite the importance and tremendous value of services provided, ecosystems and their constituent goods and services continue to decline in extent and quality.

The MA (2005) notes that all ecosystems have been transformed by human actions, with the loss of $35 \%$ of mangroves, $20 \%$ of coral reefs and it is estimated that global forest cover has decreased from $31.2 \%$ in 1990 to $30.2 \%$ in 2005 (UNEP 2006). "Over half of the 14 biomes that the MA assessed have experienced a 20-50\% conversion to human use, with temperate and Mediterranean forests and temperate grasslands being the most affected (approximately three quarters of these biome's native habitat have been replaced by cultivated lands) (MA 2005). In the last 50 years, rates of conversion have been highest in tropical and sub-tropical dry forests" (MA 2005).

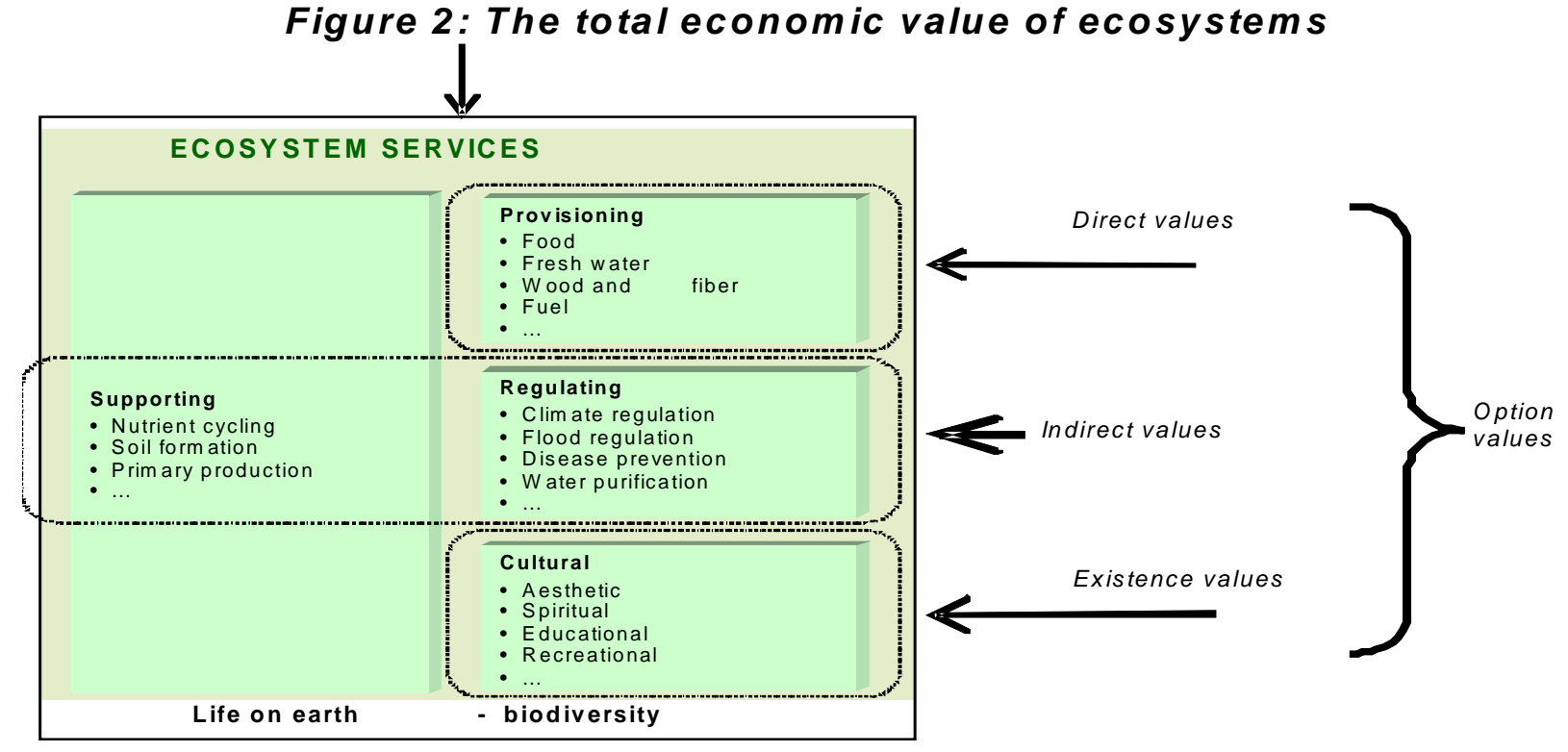

The current status and trends certainly are of concern, and the factors driving change in ecosystem services need to be more carefully examined and addressed if there is to be a reversal of loss and degradation. Of particular interest to this paper is the fact that it is often poor people who have gained the least, or have been most adversely affected, from changes in the quality of ecosystem services driven by ecosystem degradation (MA 2005). This has important implications for the value of ecosystem services and their management in increasing the well-being of the poor, an idea that will be discussed in greater detail in the following parts of this paper.

The MA report highlights the proximate and indirect drivers of change in ecosystem services. The report lays emphasis on the fact that often the driving forces impacting ecosystem services are almost 
always multiple and interactive, "so that a one-to-one linkage between particular driving forces and changes in ecosystems and ecosystem services is usually not possible" (2005).

Similarly, the linkage between particular changes in ecosystem services and various indicators of human well-being is often not well understood. In both cases, the causal linkage is almost always highly mediated by other factors, thereby complicating statements of causality or attempts to establish the proportionality of various contributors to changes. Analyses of driving forces generally distinguish between proximate drivers and the indirect drivers that themselves cause change in the direct drivers. Proximate drivers of degradation of ecosystems are reasonably well understood, at least qualitatively. For example, it is possible to identify four direct drivers of degradation and damage of ecosystems:

- The unsustainable utilization of biological resources and the consequent decline in their availability or diversity. This includes activities, which are unsustainable overall, or in terms of the areas affected, or species harvested.

- The conversion or modification (and fragmentation) of ecosystems to other uses, which do not maintain a diverse pool of species or which undermine the provision of vital ecological functions.

- The use of destructive harvesting or production techniques which impact negatively on ecosystems. This includes resource uses which negatively impact non-target species in the course of their activities.

- The alteration of environmental quality and functions that are required to maintain ecosystems. This includes production and consumption activities which generate wastes or by-products which harm the natural resource base.

The MA report identifies population growth, economic development, and increasing consumption and production as important indirect drivers of change in ecosystems and ecosystem services. However, the report points to the increasing attention being paid to the role of government policies relating to, for example, investments in rural roads, irrigation, credit systems, and agricultural research and extension, which have often served to expand food production.

Policies that restrict trade, capital, and labour flows have conditioned access to international markets, helping to shape the international food system and global patterns of food production and consumption. Small-scale food producers in many poorer countries have been particularly affected by such policies, and patterns of nutrient cycling have also been affected.

Nevertheless, the MA report does not delve further into the underlying drivers of degradation and loss of ecosystem services. Often, these underlying drivers are economic and financial in nature (Emerton, 2004). Thus a key question that arises is that if ecosystem services are so important for humans and underpin many economic activities, why is there a bias toward their destruction rather than their retention? The general findings, stemming largely from economic factors, are that people often have an incentive (either direct or indirect) to extract/use resources in such a way as to degrade and damage ecosystems. These factors have major implications for any strategy employing compensation or rewards mechanisms for managing ecosystem services, or in employing CRES as a conservation tool, to better understand and alter the incentives people have to degrade and damage ecosystems.

A major reason for degradation and damage is that ecosystems and the services they provide are undervalued and under-priced. An important contributing factor to the under-pricing of ecosystem services lies in institutional failure - both government and market failure. Market failure occurs when the lack of well-defined property rights, be they private or collective, leads to the under-valuation of ecosystem services thereby providing incentives to overuse the ecosystem service. Government failure on the other hand occurs when the public sector fails to implement the rules or norms overseeing the use of ecosystem services or create or support policies that distort the market. Both types of 
institutional failure are closely linked. Markets failures may undervalue private goods such as provisioning services, and not value public goods such as regulating, supporting and cultural services at all. In these cases, individuals often act as if the ecosystem services in question are without value (even though these services underpin the production of highly valued species or products, such as fish), leading to less than optimal production and consumption practices and hence to overexploitation and destruction.

For example, the reason why water is under-priced is that people, especially the poor, often do not have rights to clean water. If such rights did exist and were adequately enforced, then polluters would have to compensate for any adverse effects produced by their actions, providing an incentive to mitigate these actions. In the example of forests, these ecosystems are often degraded and damaged because the rights of poor local communities are either unrecognized or are unenforceable, and thus any actions they take to conserve the resources are left unrewarded.

Additionally, economic policies have at times been instrumental in creating perverse incentives that act to the detriment of ecosystem services. For example, fresh water is often under-priced in the sense that pricing structures do not reflect ecosystem management practices that optimize production and conservation, leading to overuse, pollution, and the destruction of freshwater ecosystems. Energy is under-priced to stimulate growth or investment in other sectors of the economy, leading to policies that obscure the true costs of energy production, whether based on fossil fuels, hydropower or others, especially their environmental costs. Modern agricultural technologies often aim at maximizing yields without taking into account the associated loss of ecosystem services such as soil and water quality.

Examining the problems and processes of ecosystem degradation and the loss of ecosystem services leads to a broad conclusion. Ecosystems and ecosystem services are often under-priced and undervalued for a variety of economic reasons despite the provision of tremendous economic benefits they bestow on people and society. Thus any CRES scheme in order to be effective from a conservation point of view has to provide the incentives for people to conserve and sustainably use ecosystem services.

\subsection{What is Poverty and Human Well-Being, and what are the causes and manifestations?}

To effectively address poverty reduction and human well-being, a clear understanding of what constitutes and determines poverty and how to address these with CRES schemes is essential.

The concept of poverty has been perpetually evolving since it ascendancy in the economics literature in late 1940s. Poverty, from the outset, had been inextricably linked to the amount of income required to purchase an essential basket of goods and services on the basis of nutritional content and prices of food, shelter, clothing, and so on. Therefore, households with per capita income or expenditure less than a minimum level in any given country were designated to be below the 'poverty line'. Poverty lines in this sense differed from place to place depending on national circumstances.

Poverty lines are, of course, subject to criticism, and some of the main ones call for alternative definitions of poverty insisting on subjective factors that determine whether poverty reduction initiatives assist the poor in achieving greater well-being and enriching their lives. Such concerns raised on conventional definitions of poverty have, in fact, questioned whether the only purpose of policy making is to get people above the line. Counter arguments highlight the practical advantages of thinking in terms of a line that divides the 'poor' from the 'non poor'.

In this sense, the more recent concept of dollar-a-day approach introduced in the 1990 World Development Report has been used widely. This approach too has been criticized for a number of 
reasons. For instance, it does not take into account price differentials within countries, the intrahousehold allocation of expenditure, or the difference between chronic and transient poverty. Secondly, it only values goods and services delivered through the market. Thirdly, it does not consider the non-material dimensions of poverty such as voicelessness, powerlessnes, or vulnerability to shocks, or even factors like access to common public goods and services (health, education, etc.) and common property resources (forests, pastures, fishing grounds, etc.)

As a result, definitions of poverty have broadened over time from purely monetary measures to those reflecting a multi-dimensional view of poverty and its obverse: buman well-being. The 'basic needs' approach, for example, highlighted issues relating to needs such as food, water, health, shelter, sanitation, education, and transport (Streeten et. al. 1981). More recently, while recognizing the importance of income and satisfaction of basic material needs, attention has increasingly focused on less tangible aspects of poverty, including vulnerability and access to decision-making processes, access to social services and environmental quality. ${ }^{4}$ For instance, the three fundamental causes of poverty described by the World Development Report 2000/2001 (WDR) are lack of income and assets, voicelessness and powerlessness, and vulnerability to adverse shocks. In particular, several writers have argued that the essential characteristic of poverty was captured not by incomes or production, but with what makes people fear the future - namely vulnerability (Bohle, et. al. 1994; Chambers, 1989). To be poor is to be vulnerable. To be vulnerable is to lack control over decisions that affect one's life and thus to lack self-respect, autonomy, security, sustainability and self-reliance.

The emphasis on vulnerability highlighted by the sustainable livelihoods framework (DFID, 1999) has been instrumental in raising another key issue - access to stocks of assets versus access to flows of income. The argument here is that it may be more important to focus on the assets of the poor rather than flows of income available to them, and on shocks (short-term impacts) rather than stresses (longer-term threats to income) (Chambers, 1989). Such issues have gained central importance in notions of livelihoods, and have also highlighted the particularly important role that ecosystems may take on as savings and security, especially in times of crisis. Interestingly, it is such broader conceptions of livelihoods and well-being - highlighting the role of ecosystems - that tend to emerge from self-assessments such as participatory poverty assessments undertaken recently (see for example, the Pakistan Participatory Poverty Assessment Report).

Current thinking on poverty has also been strengthened by the concept of people's capabilities provided by Amartya Sen (1979). Capabilities refer to the ability of a person to convert commodities into valued functions in the context of one's life. According to Sen, a person's life can be seen as constituted by various 'doings and beings' (or what he calls 'functionings'). People can achieve several functioningsfrom having self-respect to being well-nourished-simultaneously. Every individual can thus be seen as possessing a bundle of functionings at any given time. The set of all such bundles, all those within his/her reach at that time, is his/her capability set. The term 'capability' indicates both that he/she has internal capacities which allow him/her to function in ways that he/she might choose and that external circumstances are such that the possible functionings are indeed real options available to him/her.

Furthermore, capabilities may be defined as the substantive freedoms that an individual exercises to live a lifestyle he or she deems valuable. Choices are made through evaluative and reflective processes that lead to valuation rankings of the individual's priorities. The result of exercizing one's choices not only affords personal freedom, but is itself only achievable through the utilization of one's freedoms. Freedom, in this case, is considered both the end and the means of development. Sen identified five instrumental freedoms for the process of development to mature: political freedom, economic facilities, social

\footnotetext{
${ }^{4}$ For example, a framework developed by Moser and Young $(1986,1987,1988)$ distinguishes basic or practical needs including adequate shelter, food, water and income - from strategic needs or interests, which include citizen participation, opportunities to participate in decision-making, and empowerment.
} 
opportunities, transparency guarantees, and protective security. Duraiappah and Abraham (2004) in turn have expanded the list of instrumental freedoms to include a sixth freedom which they call ecological surety. They define ecological surety as the critical mass of an ecosystem which provides an assurance that vital regulating, supporting and enriching services are provided in a sustainable manner. These concepts in turn have played a key role in introducing subjective factors into definitions of poverty, since capabilities as Sen describes them have to be assessed within specific contexts, rather than through an objective metric.

In light of subjective factors, there is greater recognition that the poor are not homogeneous and that there may be significant differences, especially subjective, when gender and other social differences are considered and how poverty is experienced. For example, abundant literature has established the gender dimensions and differences of poverty and considerable evidence have demonstrated the multiple and complex relationships between men and women and the environment (e.g. UNEP Governing Council Decision 23/11, referring to gender equality as critical to environmental stability). Gender refers to the socially constructed differences and relations between men and women that vary by situation, context, and time.

Research on gender and poverty has focused particular attention on the household as an institutional site where prevailing norms and bargaining over needs, rights and responsibilities shape experiences of impoverishment which are differentiated by gender (Kabeer, 1991, 1994). Such research has served to highlight the particular, contextual vulnerabilities of women. Furthermore, it is important to note that women, too, are not a homogenous category: significant intra-gender differences exist in regard to age, kinship, caste, and socio-economic status (Clisby, 1995).

Gender and poverty have important implications for conservation research and action because it differentiates the relations that people establish with ecosystems, especially regarding knowledge, use, access and control of resources, and in the attitudes created towards resources and their conservation. Gender intersects with the voices of the poor, both men and women, because their interests and needs with respect to ecosystem resources (especially regarding use) will tend to be different and often even in conflict. A gender and poverty focus in conservation promotes the participation of both men and women (and youth), assures that their spheres of interest and influence are included in ecosystem management decisions, and can help to enable CRES schemes to respond to the specific social, economic, institutional and legal barriers that can hinder effective ecosystem management by men and women (Rojas, 1999).

Current thinking on poverty perhaps reflects three converging perceptions. The World Development Report 2000/2001, for example, defines poverty as 'the pronounced deprivation of well-being ${ }^{56}$. This definition includes opportunity (access to markets, resources and income generating opportunities leading to wealth creation), empowerment (influence on state institutions and participation in political processes and local decision making), and security (reducing vulnerability to risks such as ill health, economic shocks, natural disasters, and seasonal or annual variations in resource availability). Similarly, the Human Development Report has equally contributed to the current thinking on poverty. Accordingly, buman poverty is defined by "impoverishment in multiple dimensions-deprivations in a long and healthy life, in knowledge, in a decent standard of living, and in participation" (UNDP, 2004). The Human Poverty Index, or HPI, includes key measures of life expectancy, illiteracy, access to healthcare and other public services in addition to the mortality percentage of children under 5 years of age. Finally, the sustainable livelihoods framework has also played an instrumental role in influencing current

\footnotetext{
${ }^{5}$ Well-being is described as the basic material needs for a good life, the experience of freedom, health, personal security, and good social relations. Together, these provide the conditions for physical, social, psychological, and spiritual fulfilment.
} 
thinking on poverty by highlighting the concept of assets, resources and strategies of the poor, namely how the poor strategize in the face of vulnerability and use available financial, physical, human, social and natural capital to achieve positive livelihood outcomes. As a result, poverty or lack of well-being is now widely viewed as multi-dimensional and includes both income and non-income dimensions of deprivation - including lack of income and other material means; lack of access to basic social services such as education, health, and safe water; lack of personal security; and lack of empowerment to participate in the political process and in decisions that influence someone's life. The dynamics of poverty also are better understood, and extreme vulnerability to external shocks is now seen as an integral component of this understanding (UNDP, 1997).

The above discussion on what is poverty or lack of well-being inevitably leads into what constitutes well-being as defined by the MA. In fact, the MA highlights the widespread agreement that well-being and poverty are the two extremes of a multidimensional continuum. Thus well-being can be defined as the lack of poverty (see figure 3) in that it ensures basic material needs for a good life, good health, personal security, good social relations and the experience of freedom. Together these components provide the conditions for physical, social, psychological, and spiritual fulfillment.

Figure 3: Constituents of Ill-being and Well-being. Source MA (2005)
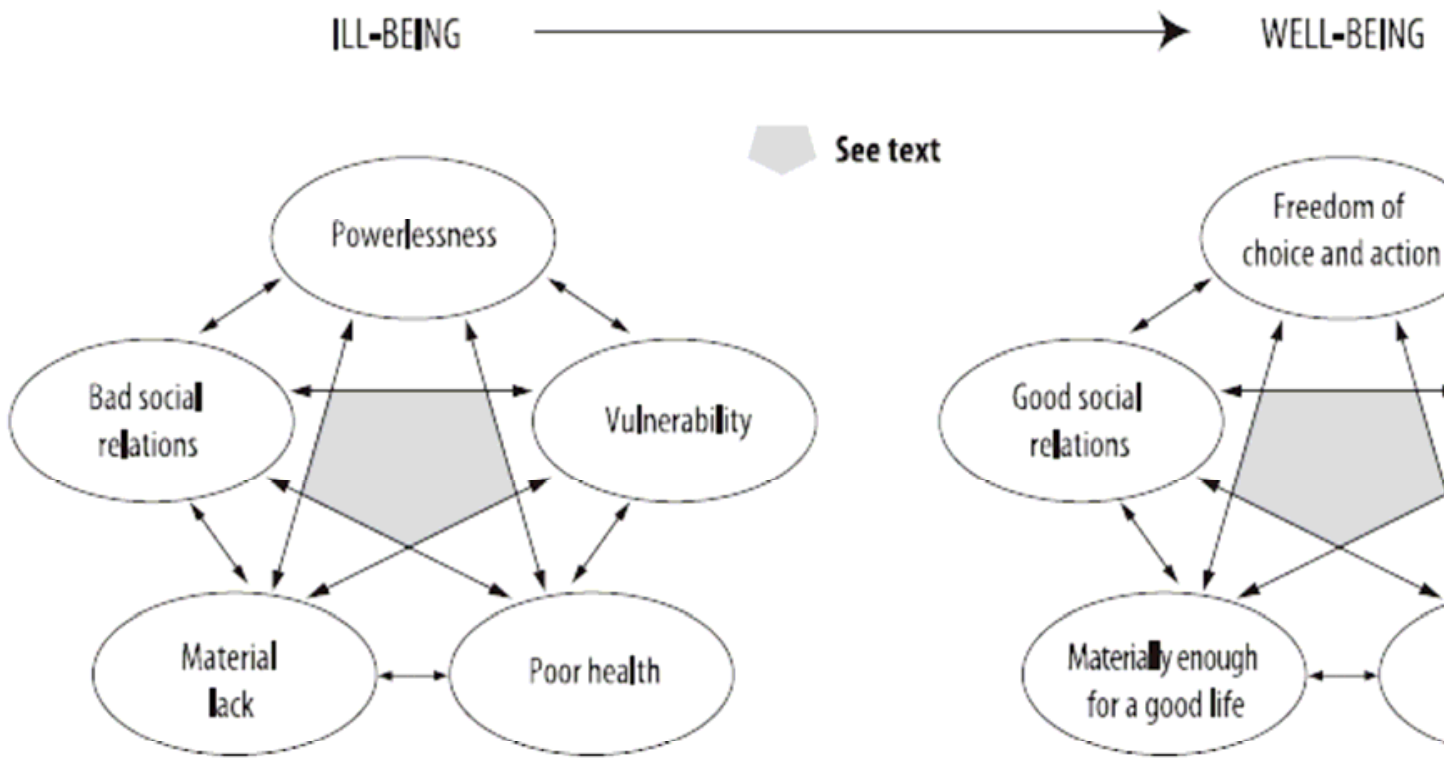

\section{See text}

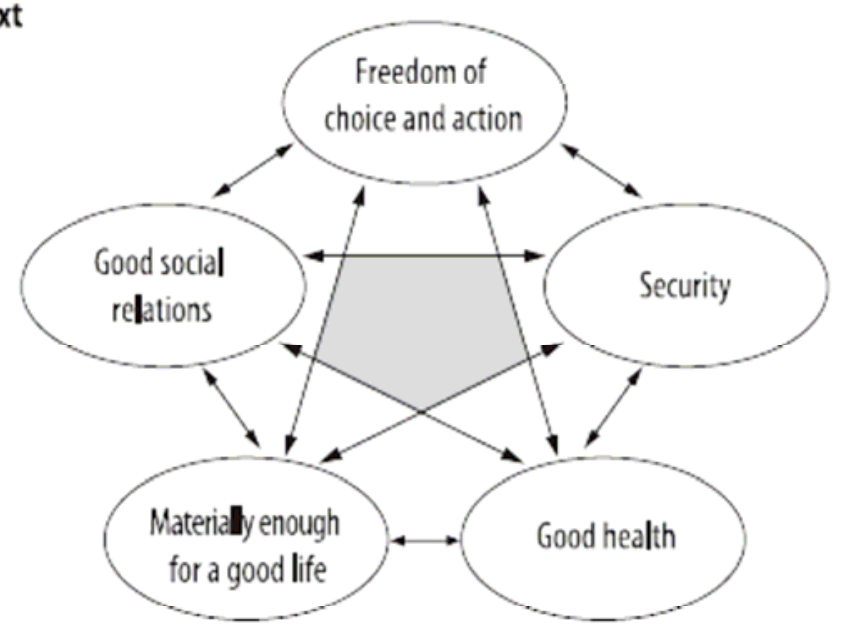

Thus borrowing from the MA (2005), the constituents of well-being can be seen as diametrically opposed to poverty:

- The necessary material for a good life (including secure and adequate livelihoods, income and assets, enough food at all times, shelter, furniture, clothing, and access to goods);

- Good health (including being strong, feeling well, and having a healthy physical environment);

- Good social relations (including social cohesion, mutual respect, good gender and family relations, and the ability to help others and provide for children); 
- Security (including secure access to natural and other resources, safety of person and possessions, and living in a predictable and controllable environment with security from natural and humanmade disasters); and

- Freedom and choice (including having control over what happens and being able to achieve what a person values doing or being) (MA 205, p. 74).

As a result of all this, measurements of poverty through indicators developed now demonstrate the more multi-dimensional nature of poverty. Select examples of developed indicators are provided in Table 2 below, and have important implication for how, where and when CRES is relevant to poverty reduction in its multifarious forms. 
Table 2: Categories of Multi-dimensional Indicators of Poverty and Well-Being

\begin{tabular}{|c|c|}
\hline Category & Multi-dimensional Indicators \\
\hline Income & $\begin{array}{l}\text { - Percentage of population below US } \$ 1 \text { per day consumption } \\
\text { - Poverty gap ratio: mean percentage distance below US } \$ 1 \\
(\mathrm{PPP}) \text { per day } \\
\text { - Percent of income based from ecosystem services at the } \\
\text { household }\end{array}$ \\
\hline Broader level indicators & $\begin{array}{l}\text { - Literacy rate } \\
\text { - Per Capita GDP (PPP) } \\
\text { - Human Development Index } \\
\end{array}$ \\
\hline Adequate nourishment & $\begin{array}{l}\text { - Per capita availability of calories } \\
\text { - Underweight prevalence } \\
\text { - Stunting prevalence }\end{array}$ \\
\hline Clean and safe shelter & $\begin{array}{l}\text { - Proportion of households with access to adequate sanitation } \\
\text { facilities } \\
\text { - Proportion of households with secure tenure, i.e. } \\
\text { o evidence of documentation that can be used as proof } \\
\text { of secure tenure status } \\
\text { o either de facto or perceived protection from } \\
\quad \text { forced evictions } \\
\text { - Percentage of population living in high risk areas } \\
\text { - Slum population as percentage of urban population }\end{array}$ \\
\hline $\begin{array}{l}\text { Access to adequate and clean } \\
\text { drinking water }\end{array}$ & $\begin{array}{l}\text { - Percentage of population with access to safe potable water } \\
\text { - Disability adjusted life years } \\
\text { - Prevalence of malaria } \\
\text { - Prevalence of diarrhoea } \\
\text { - Prevalence of hepatitis among target groups } \\
\text { - Water quality against national and World Health } \\
\text { Organization (WHO) standards }\end{array}$ \\
\hline $\begin{array}{l}\text { Reduced exposure to air } \\
\text { pollutants }\end{array}$ & $\begin{array}{l}\text { - Percentage of population using solid fuels } \\
\text { - Prevalence of acute and chronic respiratory infections } \\
\text { - Air quality against national and WHO standards }\end{array}$ \\
\hline $\begin{array}{l}\text { Access to alternative and clean } \\
\text { energy supplies }\end{array}$ & $\begin{array}{l}\text { - Energy supply (apparent consumption; Kg oil equivalent) } \\
\text { per US } \$ 1,000(\mathrm{PPP}) \mathrm{GDP} \\
\text { - Deforestation rate } \\
\text { - Percentage of households that use biomass fuels }\end{array}$ \\
\hline Access to natural resources & $\begin{array}{l}\text { - Percentage of agricultural land affected by land degradation } \\
\text { - Percentage change in per capita availability of water } \\
\text { - Percentage of forest cover of total land area } \\
\end{array}$ \\
\hline $\begin{array}{l}\text { Reduced vulnerability to extreme } \\
\text { events }\end{array}$ & $\begin{array}{l}\text { - Environmental vulnerability index } \\
\text { - Households rendered homeless by floods } \\
\text { - Frequency of droughts and floods }\end{array}$ \\
\hline
\end{tabular}




\section{Ecosystem Services and Human Well-Being: Inter-Linkages, Synergies \& Trade-Offs}

Having investigated the component elements of the MA framework separately, this section focuses on bringing them together and analysing the inter-linkages among and between them. This section is thus the lynch pin in deciphering the relationship and understanding the relevance between CRES and human well-being.

The term inter-linkage in the context of ecosystems has been used in a variety of ways and in different contexts. It is therefore useful and necessary to define what is meant by inter-linkage up front. The United Nations University (UNU) defines inter-linkage as the interactions within and between ecosystems and the inter-relation of human institutions with ecosystems (Malabed et al. 2002). In the publication Protecting our Planet and Saving our Future, inter-linkage addresses the interconnections among different environmental issues like climate change, biodiversity loss, and desertification among others. The definition we adopt in this paper relates to the interconnections not among environmental issues but among ecosystem services and also the interconnections among: (1) human well-being components like health, income and security; and (2) the interconnections between ecosystem services and wellbeing components.

There are therefore three levels of inter-linkages, which we need to acknowledge and appreciate when we want to understand the complex relationship among ecosystem services and human well-being. The first level is among ecosystem services specifically, while the second level is the inter-linkage among the various constituents and/or determinants of well-being. The third and final level of inter-linkages is between ecosystem services and the constituents and/or determinants of well-being.

\subsection{Inter-linkages among Ecosystem Services}

The MA report had identified four main categories of ecosystem services - provisioning, regulating, supporting and cultural - all of which are highly interlinked. For instance, an over use of some ecosystem services may cause a decline in other ecosystem services. It is well documented, for example, that overuse of the ecosystem provisioning service of timber can cause a decline in the ecosystem regulating service of flood and water regulation. It is also known that increasing the ecosystem provisioning service of pharmaceutical products can cause a decline in biodiversity. Although biodiversity is by itself not considered as an ecosystem service, it serves as the foundation for the health and sustainability of ecosystem services themselves. Another example is the inter-linkage between the decline in the ecosystem supporting service of nutrient cycling that comes from an unsustainable use of the provisioning service of food production (see figure 4).

The inter-linkages across these ecosystem services will need to be considered when designing CRES interventions. For example, the decision to compensate or reward the decline or increase in any particular

\section{Figure 4: Inter-linkages among ecosystem services}

\section{ECOSYSTEM SERVICES}

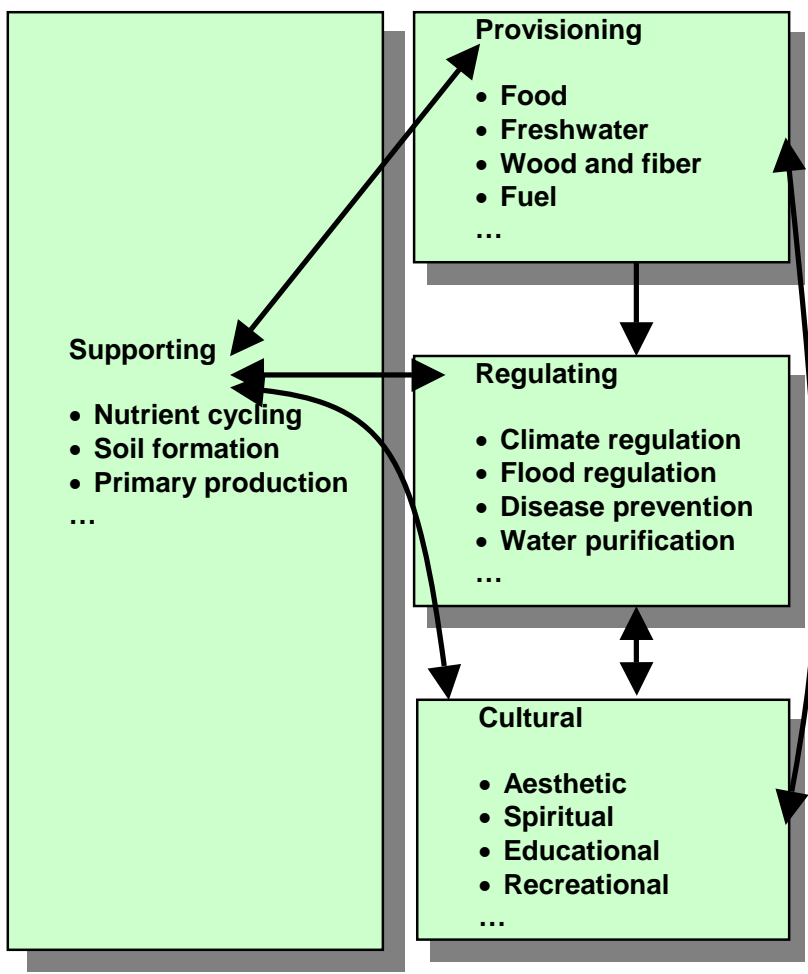

Life on earth - Biodiversity 
ecosystem service will be dependent on the marginal changes that occur across the ecosystem services that are inter-linked. For example, in the Wealth of the Poor report (WRI, 2002), there was much emphasis on ensuring a sustainable stream of environmental 'income' as the strategy for poverty reduction. However, a sustainable stream of environmental income which implies a sustainable flow of provisioning ecosystem services may not be consistent with maintaining the integrity of the ecosystem and therefore the sustainability of flow of the regulating, supporting and cultural services. Therefore, ecosystem services like disease regulation may increase, flood regulation may decrease, and water regulation and purification services may deteriorate

\subsection{Inter-Linkages among Constituents and Determinants of Human well-being}

There is no doubt that human wellbeing is multi-dimensional and is Figure 5: Inter-Linkages among Constituents and determined by a range of constituents and determinants directly and indirectly (see figure 5). Constituents are ends by themselves while determinants are the means to the ends. In other words, constituents can be thought of as 'output' (such as health, the exercise of one's abilities, and civil and political liberties), whereas, the determinants can be thought of as 'inputs' (expenditure on food, clothing, education, potable water, shelter, and resources deployed for the protection and promotion of civil and political liberties) (Dasgupta, 2003). It is not the purpose of this paper to carry out a discourse between the philosophical discussion on the merits of using constituents or determinants. The decision to use a constituent or determinant will be largely influenced by the data and information available and in cases where constituents are difficult to observe, then determinants are used as proxies (Dasgupta, 2003). What is

\section{Determinants of Human well-being}

CONSTITUENTS OF WELL- BEING

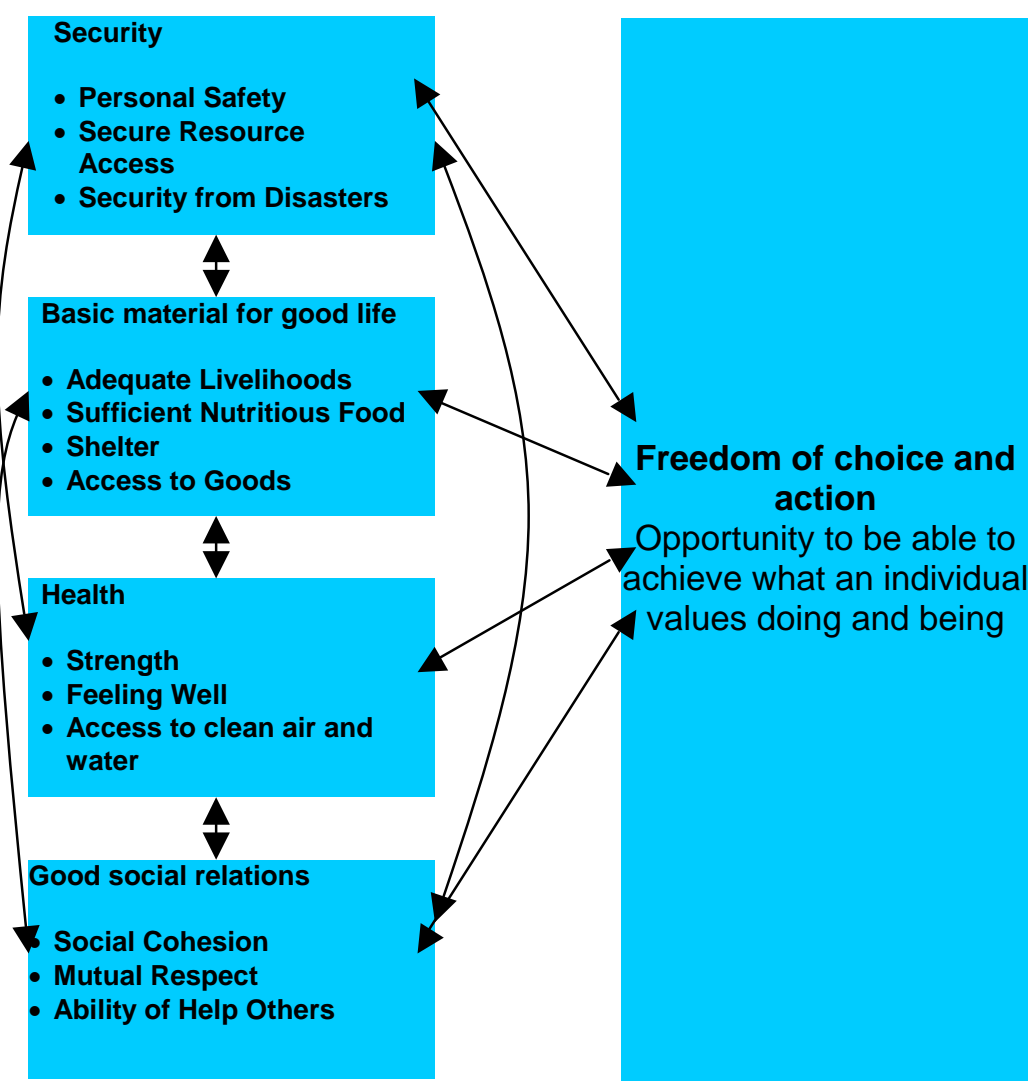
useful for us is to understand that there are inter-linkages across components of well-being, be they constituents or determinants.

The inter-linkages among constituents can be quite strong or weak depending on factors like gender and culture. For example, women's ability to be free from avoidable diseases is highly inter-linked with the ability to have energy for cooking and keeping warm, or access to clean water. The dependency of using firewood as a primary energy source, taking another example, tends to increase health impacts from asthma and or other respiratory diseases. Similarly, the ability to be adequately nourished and earn material wealth often incurs a decline in social relations related to spiritual practices involving sacred ecosystems, closely linked with culture. 


\subsection{Inter-Linkages across Ecosystem Services and Constituents of Well-Being}

The final level of inter-linkages discussed here are those between a specific link between an ecosystem service and the constituent of well-being vis-à-vis a link between another ecosystem service and the respective constituent of well-being. For example, the link between timber and material wealth versus flood regulation and security. The information of this linkage will tell us the marginal changes that occur in the constituents of well-being when there are changes in the ecosystem services.

\subsection{Ecosystem Services and Human Well-Being - Synergies and-Trade-Offs}

As mentioned above, there are inter-linkages among ecosystem services, among constituents of wellbeing and across ecosystem services and constituents of well-being. And these can have different dimensions depending on factors like gender, culture, spatial location and time. For example, women's ability to access provisioning services (e.g. timber) may be affected by social and cultural restrictions, which in turn may increase the provision of some regulating service (e.g. carbon storage). However, access to benefits in terms of rewards from the increased supply of this regulating service may even improve their overall well-being.

The discussion above on inter-linkages immediately highlights the presence of synergies and trade-offs. For example, improvement in the supporting service of soil formation inadvertently improves the food production provisioning service. However, the potential for trade-offs is also present. For example, the over extraction of timber (a provisioning service) can cause a decline in flood regulation (a regulating service) within the vicinity of where the timber is extracted or further down from where the timber is located. In similar fashion, an improvement in health contributes to an increase in material wealth as productivity increases. However, trade-offs are also present in the social system where an increase in material wealth can come at the expense of security. For example, an increase in material wealth driven by the extraction of timber causes a loss in security which comes from an increase in the frequency of extreme events. Trade-offs and synergies among human well-being, ecosystems and ecosystem services are the rule rather than the exception (MA 2005). Closely associated with the three levels of linkages, are the four dimensions of trade-offs and synergies. These are:

1. Trade-off and synergies among ecosystem services

2. Trade-offs and synergies between the present and the future

3. Trade-off and synergies among stakeholders

4. Trade-offs and synergies across spatial boundaries.

\subsection{Trade-offs and Synergies among Ecosystem Services}

The Oxford Dictionary defines synergy as "a combined effect ... that exceeds the sum of individual effects". In short, synergy is when $2+2+2$ is greater than 6 . In the literature on synergy, most efforts are focused towards reaping synergies when using common policy tools to achieve multiple objectives. Therefore, because of the inter-linkages among ecosystem services, it is possible to reduce the decline in two ecosystem services which are closely inter-linked by a single tool and therefore reducing the cost and efforts. An example of synergies is the link between climate change and biodiversity. The Kyoto Protocol is an international treaty addressing the decline in the global climate regulation ecosystem service. The decline in this service can be expected to cause a decline in biodiversity which is essential for many ecosystem services including water purification and pollination (MA 2005). The CDM, a policy mechanism of the Kyoto Protocol can be used if designed properly to also help reduce the decline in biodiversity and be a tool for biodiversity conservation. This helps reduce the cost and 
efforts necessary to establish a separate economic mechanism for the conservation of biodiversity. As the saying goes, we are able to kill two birds with a single stone.

\subsection{Trade-offs and Synergies between the Present and the Future}

One of the most well-known examples of the trade-off between the present and the future is that of climate change. The increase in the present generation's material wealth derived from the excessive use of provisioning services like food production, timber and fibre among others has caused significant impacts on the global climate regulation systems. However, the consequences of the decline in the climate regulation system will not be experienced by this generation but future generations because of the inertia in the natural system (MA 2005). The benefits reaped by the present generation will need to be evaluated against the costs to be borne by future generations. In many ways, the issue of intergenerational equity comes into discussion.

\subsection{Trade-off and synergies among stakeholders}

Most poor people, and particularly women, are heavily dependent on ecosystem services for their wellbeing, but suffer from inadequate access and declining quality of such services. Ecosystem services are vital for the poor by fulfilling subsistence, non-marketed and cash needs. For example in India, Jodha (1986) estimated the proportion of household income from ecosystem provisioning services to be 15$25 \%$. More recently work on village data from Zimbabwe reported the proportion to be as high as $40 \%$ for the poorest households (Cavendish, 2000). Provisioning services often include essential items for personal use and sale including food, fodder, fuel, fibre, small timber, manure, bamboos, medicinal plants, oils, material for houses and furniture etc. For poor coastal communities in developing countries, fisheries is a key provisioning service, and many farm households augment their food supplies and incomes by fishing (UNEP 2002). All these represent the inter-linkage between provisioning services and the basic material for good life.

Many poor people's health and well-being is subjected to environmental health risks and hazards both the traditional risks of dirty air and water as a result of declining ecosystem regulatory services. Poor people suffer from lack of access to improved water sources and sanitation.

The poor are the most vulnerable to natural disasters. The poor tend to suffer most and find it difficult to cope, as they live in the most vulnerable areas, e.g. many slum dwellers live on land which is highly vulnerable to environmental hazards such as landslides, pollution and floods. Such vulnerabilities are exacerbated by damage to protective ecosystem services provided by coral reefs, coastal mangrove forests and riverine wetlands, which increase exposure to floods.

At the same time, it is often the non-poor and more powerful stakeholders who have gained the most from changes in the quality of ecosystem services driven by ecosystem degradation. However, changes in the quality of ecosystem services impacts these stakeholders too (particularly those, for example, who rely on water quantity and quality services for agriculture, hydropower and domestic use), which provides pathways for synergies between the interest of both the poor and non-poor through CRES options.

Furthermore, CRES options that consider restricting use of, or degrading key ecosystem services, change in land use regimes, or prevent the uptake of other income-generating opportunities can impose tremendous costs onto these households. Under these circumstances, some ecosystem services and constituents of well-being will have the potential of being traded off against other key ecosystem services and constituents of well-being of the poor. CRES schemes need to be particularly cognizant of 
these trade-offs, and find ways to compensate or reward poor households that may lose access to resources due perhaps to insufficient rights or tenure.

\subsection{Trade-offs and synergies across spatial boundaries}

In many instances, the changes in ecosystem services happen in one place while the consequences on well-being takes place in different places. For example, changes in land use in the Catskill water catchments caused a reduction in water quality for the residents of New York City. A more familiar example is the emission from coal powered energy stations in England caused forests and lakes in Norway to die and cause a decline in the ecosystem service of food production and water regulation among others.

These examples of synergies and trade-offs point towards a pivotal role for integrated ecologicaleconomic assessment in assessing inter-linkages, synergies and trade-offs. As mentioned above,

Figure 6: Valuation provides a mechanism for assessing interlinkages, synergies and trade-offs between and across ecosystem services and constituents of hum an well-being

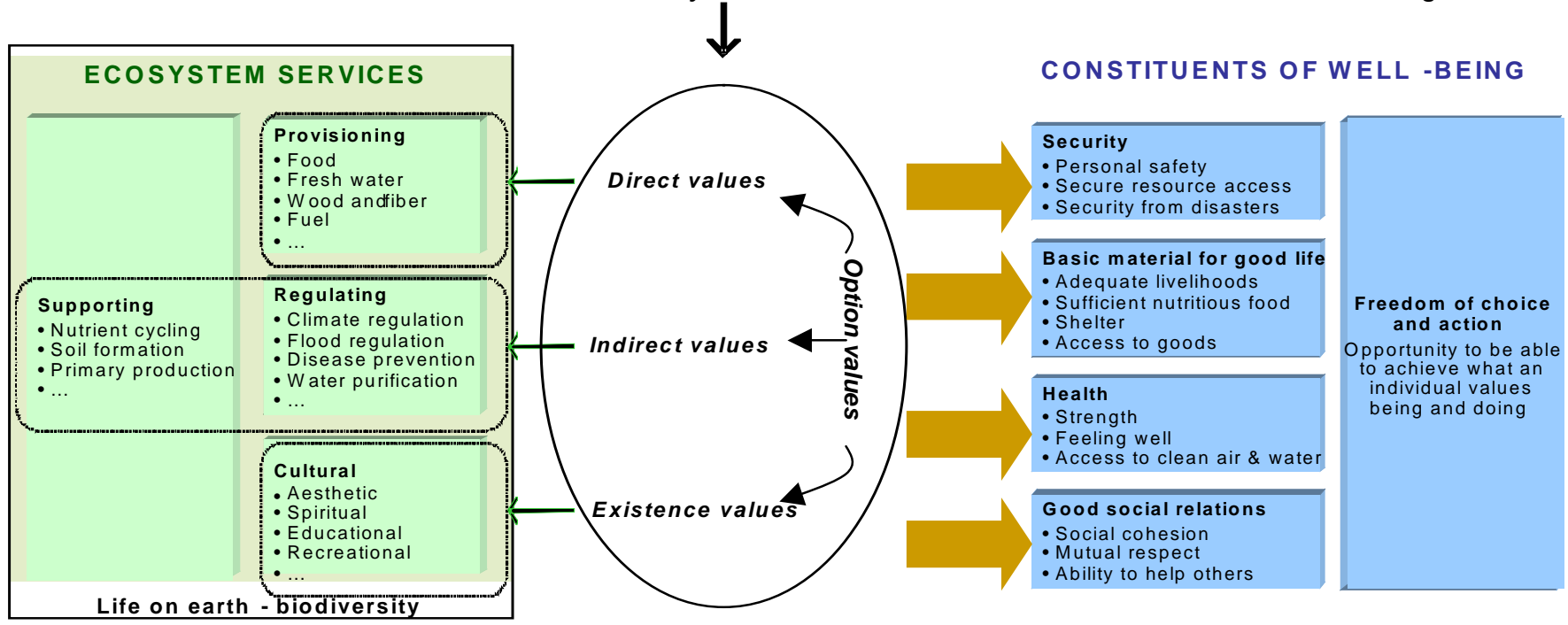

integrated assessments establish the relationship between land and ecosystem use (and by whom), and the provision of ecosystem services, point towards the magnitude and direction of change and the stakeholders affected. For example, the economic valuation of ecosystem services, as part of the integrated assessment, may reveal tremendous indirect values to off-site from the increase in regulating and supporting ecosystem services and this may increase security of well-being of the poor off-site. But on-site restriction to provisioning services may impact the livelihoods, food security and health wellbeing of the poor, especially women. Economic valuation would reveal the imposed costs of loss of provisioning services and would thus allow comparison of the trade-offs both of the ecosystem services and the constituents of well-being (see figure 6 above). Figure 6 brings together the MA framework with the Total Economic Value of Ecosystems framework to particularly highlight interlinkages in quantitative terms, and where synergies are possible and where trade-offs are inevitable. This has important implications for the design of CRES schemes. 


\section{Status of Rewards and Compensation for Ecosystem Services \& Poverty Reduction - Experiences to date}

There has been considerable interest and initiative in payments for environmental services (henceforth RES according to our terminology) throughout the developing world, and many NGOs, research institutions and donors are now working on this issue. The tool is being touted with the potential to directly address conservation, and benefit the poor. It is imperative, however, to bear in mind that the original and prime motivation of RES is to meet conservation goals rather than being pro-poor. If benefits to the poor occur these are unintended outcomes rather than products of conscious design, a fact supported in the literature on this subject. The number of RES schemes, which claim to be propoor is very limited (Landell-Mills and Porras, 2002). The Costa Rica programme, for example, has so far favoured mainly larger and wealthier landowners (Mirinda et al., 2003). Some even state that RES schemes on their own are not recommended for poverty alleviation, and excessive reliance on the mechanism could even lead to adverse poverty outcomes (CES Latin American Workshop Report, 2007, ICRAF Working Paper no. 33). That being said, the existing RES schemes found around the world have themselves not been adequately assessed, and pro-poor outcomes may in fact exist. It is, however, not clear in the literature how the poor may have benefited, from these exercises, or indeed how pro-poor is being defined.

Nevertheless, there is growing evidence, lessons and recommendations found in the literature on RES and the relationship to the well-being of the poor. Many researchers are coming to the conclusion that the extent to which RES is able to serve the multiple goals of conservation and well-being depends on the design and implementation of such schemes. For example, de facto property rights of the poor to land and resources are increasingly being recognized, but often the landless are unable to benefit unless special provisions are made (such as the provision of community rewards as opposed to rewarding individual farmers). Furthermore, the ecosystem service in question, and the location of the ecosystem and the poor, will also determine to what extent the poor can benefit from RES schemes. It is often thought, for example, that poor subsistence farmers inhabit upper watersheds - critical sources of ecosystem water services - and hence RES schemes for watersheds are often assumed to be pro-poor, whether or not this assumption was directly assessed (Pagiola and Platais, 2003).

The literature, however, tends to highlight the negative impacts of RES schemes on the well-being of the poor. For example, it is often pointed out that there are a number of obstacles to include the poor in RES schemes, which include issues of insecure property rights and land tenure; lack of financial resources, capacity and bargaining power; weak cooperative institutions; and high transaction costs (Mayrand and Paquin, 2004; Landell-Mills and Porras, 2002; Pagiola et al., 2005). In the above Costa Rican programme, for example, only one third of small landholders (owning less than $10 \mathrm{ha}$ ) have signed up in this scheme (Miranda et al. 2003).

One of the key lessons emerging from the literature is that often RES schemes fail to undertake (sitespecific) integrated ecological-economic assessments, which assess the relationship between land and ecosystem uses (and by whom) and the provision of ecosystem services linking these to the calculation of economic costs and benefits and their distribution for the purposes of determining rewards (Tongetti, et. al.). The purpose of these assessments is to assess the biophysical relationships, identify the beneficiaries (buyers) and the providers (sellers), but more importantly, ensure that compensatory arrangements pay close attention to the fact that the added costs of conservation actions in the form of opportunity costs of forgone land uses are offset by the reward. Without an integrated assessment, the poor may often become invisible in the analysis and RES schemes may be based on simplistic myths or assumptions about land and resource use and ecosystem services (Tongetti et. al., no date). 
More specifically the threats to the poor identified in the literature are:

Insecure property rights and land tenure - Formal land titles and secure property rights are one of the foundations of any RES scheme. Land ownership is almost always used to identify potential service providers and hence who should receive the reward. The poor often lack or have unclear and insecure property rights over land and resources.

Lack of financial resources, capacity and bargaining power - Insufficient credit and start-up funds can restrict participation in RES initiatives and mean that poor land users cannot afford to take risks. Also, there are often high initial costs involved with such schemes as eco-labelling (e.g. timber certification) and carbon credits under the Clean Development Mechanism (Sheer and Smith, 2000). Furthermore, the poor usually do not possess the necessary capacity and competence to make changes in their systems of resource use and land management. Finally, lack of bargaining power and voice can often result in arrangements where the poor are not adequately rewarded as service providers, or worse sidelined by more powerful and wealthier land owners or 'elites' (Grieg-Gran and Bann, 2003),

Weak cooperative institutions - Lack of institutional support to participate in RES schemes often leads to the exclusion of poorer households. This is supported by current experiences, which suggest that private PES schemes tend to arise in areas with higher incomes and better institutions and infrastructure (Landell-Mills and Porras, 2002).

High transaction costs - The costs of drawing up a contract and monitoring performance can become a considerable burden on poorer households, ultimately resulting in their de facto exclusion from a RES scheme.

The literature has also brought to light potential benefits/opportunities and associated costs/risks that have important ramifications for the design and implementation of pro-poor RES schemes. These include:

\section{Potential benefits/opportunities:}

- Increased land/resource tenure security - resulting from formalization of property rights land tenure.

- Improved health - resulting from investments in medical facilities and conservation and pollution mitigation measures.

- Strengthened social institutions - resulting from cooperative arrangements that support evolving markets.

- Skill development - resulting from training in e.g. natural resource management.

- Improved recreation and cultural opportunities - resulting from environmental conservation and the protection of cultural heritage and religious sites.

- Diversified and increased rural income - resulting in lessening household vulnerability and risks from shocks.

- Increased productivity - resulting in more sustainable farming and forest systems for local livelihoods (biomass, water, biodiversity services).

- Improved/maintained ecosystem services - resulting in watershed maintenance, pollinator species and soil control, contributing to human well-being.

- Improved business and market organization - resulting in local communities, fostering and enabling future growth and economic development. 


\section{Potential cost/risks:}

- Restricted land uses and natural resource extraction - resulting in loss of livelihoods and income.

- Reduced health - resulting from loss of access to natural resource based foods and hence impacting food security.

- Elite capture - resulting from the wealthier and more powerful groups having the ability to pay.

- Increased land prices - resulting from an increased demand for land.

- Loss of cultural heritage - resulting from abandoning traditional land-use systems.

- Loss of employment - resulting for instance from the exclusion of resource harvesting rights through ecosystem service protection, or when less labour is required under new land uses and excess labour can not be redirected to other income generating activities.

- Loss of control and flexibility over local development options and directions - resulting from situations where easements or long-term contracts specify a narrow range of management alternatives, or where community land owners or dwellers do not become involved.

- Skewed local power structures or power base - resulting from an unequal distribution of rewards.

- Increased competition - resulting from markets that lead to the further marginalization of weaker groups.

The regional workshops organized as part of this project deliberated on most of the points mentioned above. The potential way forward for developing pro-poor RES were also discussed and resulted in the following recommendations (Latin America workshop report, 2006):

- Need to ensure that transaction costs are kept low;

- The poorest sectors of society are specifically targeted;

- Assistance is provided to enable the poor to participate;

- The reward covers opportunity costs thereby creating an incentive for land-use change;

- The local landscape of formal and informal property rights is clearly identified and understood.

Also in Landell-Mills and Porras (2002) a number of suggestions for promoting pro-poor markets have been presented, and include:

- Formalize forest service property rights held by the poor;

- Define appropriate ecosystem services;

- Devise cost-effective reward mechanisms;

- Strengthen cooperative institutions;

- Invest in training and education;

- Establish a market support center;

- Improve access to finance, particularly micro credit.

However, the impact on the poor will vary considerably depending on the local circumstances of the poor. Specific findings include:

- Generally speaking, PES is good for landowners as producers because either they directly get environmental services that are of greater than the value of the production that they give up, or they benefit from changes in prices, which increase output price and sometimes reduce labour prices

- Poor consumers may lose from environmental services. For example, the urban poor may be negatively affected by an environmental services programme that reduces the production of local staples, resulting in higher food prices 
- Particularly when it comes to land diversion programmes, labourers may lose as the demand for labour declines

- The distribution of lands matters. If land distribution is unequal and landowners have minimal amounts of lands and much of their income is coming from their labour, then especially when it comes to land diversion programme, they may lose work or suffer reduced wages

- In general the poor are more likely to benefit from working land programmes (that modify production) where these increase demand for labour.

The paper notes that an assessment of the poverty impacts of any PES programme should also consider:

- The measurement of poverty and inequality in assessing benefits of any PES programme, taking into account not only earnings but any changes in the cost of living

- 'Slippage', whereby landowners bring new areas of land into production, potentially offsetting the positive effects of the PES programme

- Risk aversion behaviours of landowners and any impact on the risk of food insecurity for the local poor arising from changes in local food production and wages.

\subsection{Status of Compensation for Ecosystem Services \& Poverty Reduction - Experiences to date}

There has been little experience of compensation for ecosystem services and its relation to poverty reduction to date. Experience with regulatory instruments such as pollution charges and newer instruments such as tradable permits, conservation offsets and concessions have been largely related to their use as conservation tools. However some preliminary lessons on the relationship between CES and poverty reduction are available:

- The impact on poverty from compensation for ecosystem services (CES) may have no specific connection to poverty or at best the connection seems to be poverty neutral. For example, compensation evoked through the polluters/damagers pay principal normally leaves the poor no better off.

- Nevertheless, if a compensation structure if it operates as a long-term disincentive to pollute/damage, then this approach may address poverty reduction.

- The rights of the poor must be clearly defined with respect to compensation against ecosystem services degradation and damage.

- Biodiversity/ecosystem offsets can both exacerbate and reduce poverty. Those who suffer most from loss of ecosystem services on site are often not compensated, while offsetting these costs by investing in another ecosystem could potentially reduce poverty, but with other individuals / communities benefiting.

The above review provides a necessary background to understanding the interface between CRES and poverty reduction, and the well-being of the poor. The literature evidently points out that there have not been any lucid frameworks developed to assess the pro-poor potential of CRES. At best, different constituents of poverty are assessed without systematic treatment of the linkages between CRES and poverty reduction and the well-being of the poor. In the following sections a conceptual framework is developed and presented for this purpose. 


\section{Findings: What is the relevance of CRES to poverty reduction and human well-being?}

This section builds on the learning from the previous sections, and focuses on the practical relevance of CRES to poverty reduction and well-being of the poor through the framework developed in figure 6 above. This section begins with a definition of pro-poor, and then move towards the relevance of CRES to poverty reduction: how and when is it relevant and where.

\subsection{How do we define pro-poor?}

For the purposes of this paper, pro-poor is defined as the increase in benefits (through rewards) and/or decrease in costs (through compensation) in monetary and non-monetary forms that should lead to increased well-being of the poor and reduction of poverty. In broad terms there are two different interpretations of pro-poor - depending on whether poverty is measured in absolute or relative terms.

Absolute definition: Under this interpretation, CRES will be pro-poor as long as the poor benefit from compensation and rewards. Pro-poor can then be defined to exist as long as the indicators of poverty and well-being are not stagnant or in decline. This means that no consideration is given to the distribution of benefits.

Relative definition: According to this interpretation, promoting pro-poor CRES requires a strategy that is deliberately biased in favour of the poor. A precise definition of pro-poor must then mean that the proportional benefits or compensation to the poor must exceed the average benefits or compensation of the particular CRES scheme.

Often the relative definition may not be feasible, as will be apparent from table 3 below, and hence emphasis should be that the absolute definition at a minimum is adopted for any CRES scheme to be pro-poor. In the specific case of compensation for ecosystem services, it may be problematic to have increases in well-being of the poor through compensation, as this may make the poor no better off.

\subsection{Is CRES relevant to Poverty Reduction and Human Well-Being? When? How?}

With the definition of pro-poor at hand, it is possible to explore the relevance and inter-linkages (synergies and trade-offs) between CRES and poverty and human well-being in qualitative terms. That is, an assessment can be taken of circumstances in which CRES is relevant to poverty reduction and well-being and it is possible for the poor to benefit from CRES, and circumstances in which CRES leads to inevitable trade-offs. Table 3 below is precisely designed to illustrate the relevance of CRES to poverty reduction and well-being, and includes the key factors enabling when the poor can benefit. Table 3 also enlists the different CES and RES scheme types, a brief description of them as well as the types of instruments used (for a more detailed explanation of these typologies please refer to the introductory paper of this series, ICRAF Working Paper no. 32). 
Table 3: CRES relevance to Poverty and Human Well-Being

\begin{tabular}{|c|c|c|c|c|}
\hline $\begin{array}{l}\text { CRES } \\
\text { Type }\end{array}$ & Brief Definition & $\begin{array}{c}\text { Types of } \\
\text { Instruments }\end{array}$ & $\begin{array}{c}\text { CRES Relationship } \\
\text { to Poverty Reduction } \\
\text { and Well-being - } \\
\text { Synergies and Trade- } \\
\text { offs }\end{array}$ & $\begin{array}{c}\text { When is CRES relevant to } \\
\text { Poverty Reduction and } \\
\text { Well-being }\end{array}$ \\
\hline CES 1 & $\begin{array}{l}\text { 'Polluters pay' } \\
\text { compensation for } \\
\text { damage inflicted. } \\
\text { These are non- } \\
\text { voluntary } \\
\text { arrangements. }\end{array}$ & $\begin{array}{l}\text { - Monetary } \\
\text { payme } \\
\text { Non- } \\
\text { monetary } \\
\text { payments }\end{array}$ & $\begin{array}{l}\text { Trade-offs } \\
\text { - Compensation } \\
\text { through monetary } \\
\text { payments can offset } \\
\text { large income and } \\
\text { livelihood losses to } \\
\text { the poor. } \\
\text { - Potential } \\
\text { improvements to } \\
\text { health and } \\
\text { education of the } \\
\text { poor through non- } \\
\text { monetary payments } \\
\text { (health and } \\
\text { education facilities), } \\
\text { however, exposure } \\
\text { to environmental } \\
\text { health risks (dirty } \\
\text { water and air) and } \\
\text { hazards remains. }\end{array}$ & $\begin{array}{l}\text { - Instrument might be } \\
\text { poverty reduction neutral } \\
\text { however the poor can } \\
\text { benefit by the following: } \\
\text { - Rights to compensation, } \\
\text { especially for the poor, are } \\
\text { defined and defendable } \\
\text { - Social mobilization allows } \\
\text { the poor and marginal } \\
\text { groups to access } \\
\text { compensation }\end{array}$ \\
\hline
\end{tabular}




\begin{tabular}{|c|c|c|c|c|}
\hline $\begin{array}{c}\text { CRES } \\
\text { Type }\end{array}$ & Brief Definition & $\begin{array}{c}\text { Types of } \\
\text { Instruments }\end{array}$ & $\begin{array}{c}\text { CRES Relationship } \\
\text { to Poverty Reduction } \\
\text { and Well-being - } \\
\text { Synergies and Trade- } \\
\text { offs }\end{array}$ & $\begin{array}{c}\text { When is CRES relevant to } \\
\text { Poverty Reduction and } \\
\text { Well-being }\end{array}$ \\
\hline CES 2 & $\begin{array}{l}\text { From the 'sellers' } \\
\text { perspective, trading } \\
\text { away the rights to } \\
\text { pollute or rights to } \\
\text { ecosystem resource } \\
\text { use; from the } \\
\text { 'buyers' it can be } \\
\text { either (a) an } \\
\text { opportunity to } \\
\text { 'offset' transactions, } \\
\text { or (b) a buyer with } \\
\text { a conservation } \\
\text { objective who buys } \\
\text { the rights in order } \\
\text { not to utilize them } \\
\text { (e.g. the } \\
\text { conservation } \\
\text { concession } \\
\text { concept). These are } \\
\text { often non- } \\
\text { voluntary } \\
\text { arrangements. }\end{array}$ & $\begin{array}{ll}\text { - } & \text { Tradable } \\
\text { permits } \\
\text { - } & \text { Conservation } \\
\text { Offsets and } \\
\text { - } & \text { Concessions }\end{array}$ & $\begin{array}{l}\text { Synergies } \\
\text { Potential improved } \\
\text { security at sites } \\
\text { where permits, } \\
\text { concessions and } \\
\text { offsets are } \\
\text { purchased through } \\
\text { reduced exposure } \\
\text { to environmental } \\
\text { health risks (dirty } \\
\text { water and air) and } \\
\text { hazards on poor } \\
\text { households. } \\
\text { Improved } \\
\text { livelihoods where } \\
\text { tradable permits, } \\
\text { offsets and } \\
\text { concessions result } \\
\text { in enhanced } \\
\text { provision of } \\
\text { ecosystem services. } \\
\text { Access to social } \\
\text { investments } \\
\text { through all three } \\
\text { instruments and } \\
\text { thus improvement } \\
\text { in health and } \\
\text { education. } \\
\text { Trade-offs } \\
\text { Potential reduced } \\
\text { security of the poor } \\
\text { where damage } \\
\text { occurs but no } \\
\text { mitigation actions } \\
\text { are taken. }\end{array}$ & $\begin{array}{l}\text { 1. For the case of tradable } \\
\text { permits, the rights of the } \\
\text { poor over resources and } \\
\text { thus ecosystem services } \\
\text { that can be traded. } \\
\text { 2. For the case of offsets, } \\
\text { schemes where offsets } \\
\text { apply and where the poor } \\
\text { exist and benefit from } \\
\text { improved ecosystem } \\
\text { services at offset site. } \\
\text { 3. For the case of } \\
\text { concessions, rights of the } \\
\text { poor over resources and } \\
\text { thus ecosystem services } \\
\text { rewards that can be } \\
\text { exchanged. } \\
\text { 4. Ability to access tradable } \\
\text { permits and concessions } \\
\text { 5. Ecosystem restoration } \\
\text { and clean up efforts are } \\
\text { undertaken over time as } \\
\text { part of compensation. }\end{array}$ \\
\hline
\end{tabular}




\begin{tabular}{|c|c|c|c|c|}
\hline $\begin{array}{c}\text { CRES } \\
\text { Type }\end{array}$ & Brief Definition & $\begin{array}{c}\text { Types of } \\
\text { Instruments }\end{array}$ & $\begin{array}{c}\text { CRES Relationship } \\
\text { to Poverty Reduction } \\
\text { and Well-being - } \\
\text { Synergies and Trade- } \\
\text { offs }\end{array}$ & $\begin{array}{c}\text { When is CRES relevant to } \\
\text { Poverty Reduction and } \\
\text { Well-being }\end{array}$ \\
\hline RES 1 & $\begin{array}{l}\text { Provides rewards } \\
\text { for 'stewardship' of } \\
\text { ecosystem services } \\
\text { provision. These } \\
\text { can take the form } \\
\text { of voluntary } \\
\text { arrangements. }\end{array}$ & $\begin{array}{l}\text { Monetary } \\
\text { payments, } \\
\text { Community } \\
\text { social } \\
\text { investment. }\end{array}$ & $\begin{array}{l}\text { Synergies } \\
\text { - } \quad \text { Improved food } \\
\text { security and higher } \\
\text { productivity from } \\
\text { sustainable farming } \\
\text { and enhanced } \\
\text { ecosystems. } \\
\text { - Increased and } \\
\text { diversified incomes. } \\
\text { - Increased health } \\
\text { and education and } \\
\text { other social } \\
\text { investments. } \\
\text { Increased access to } \\
\text { alternative, clean } \\
\text { energy supplies. } \\
\text { Reduced } \\
\text { vulnerability of the } \\
\text { poor to withstand } \\
\text { shocks and stresses. } \\
\text { Trade-offs } \\
\text { Reduced access and } \\
\text { stricter land use } \\
\text { regulation result in } \\
\text { loss of livelihood } \\
\text { and income. }\end{array}$ & $\begin{array}{l}\text { 1. The ability of the poor to } \\
\text { access financial capital to } \\
\text { make investments. } \\
\text { 2. The ability of the poor to } \\
\text { access rewards. } \\
\text { 3. The ability and capacity of } \\
\text { the poor to comply with } \\
\text { the RES agreement. } \\
\text { 4. Recognition of the poor } \\
\text { as the de facto or de jure } \\
\text { land managers needed to } \\
\text { establish additionality. }\end{array}$ \\
\hline RES 2 & $\begin{array}{l}\text { Aims at avoiding } \\
\text { losses and } \\
\text { maintaining } \\
\text { environmental } \\
\text { qualities over and } \\
\text { beyond existing } \\
\text { legal protection. }\end{array}$ & $\begin{array}{l}\text { Monetary } \\
\text { payments, } \\
\text { Community } \\
\text { social } \\
\text { investment. }\end{array}$ & $\begin{array}{l}\text { Synergies } \\
\text { - Increased and } \\
\text { diversified incomes } \\
\text { and livelihoods } \\
\text { through rewards } \\
\text { - Increased health } \\
\text { and education } \\
\text { - Increased access to } \\
\text { alternative energy } \\
\text { supplies } \\
\text { Recognition of } \\
\text { traditional } \\
\text { sustainable land } \\
\text { management } \\
\text { practices } \\
\text { Reduced } \\
\text { vulnerability of the } \\
\text { poor to withstand } \\
\text { shocks and stresses }\end{array}$ & $\begin{array}{l}\text { 1. The ability of the poor to } \\
\text { access rewards. } \\
\text { 2. Recognition of the poor } \\
\text { as the de facto or de jure } \\
\text { land managers needed to } \\
\text { establish additionality. }\end{array}$ \\
\hline
\end{tabular}


In essence, the relevance of CRES to poverty reduction and well-being is clearly revealed through the nature of benefits and/or costs avoided as a result the potential rewards and compensation schemes. In the case of both compensation and rewards, these include:

- Improved security through decreased exposure to environmental health risks (dirty water and air) and hazards that often impacts most on poor households.

- Improved access to increased income, goods and/or services through compensation in monetary and non-monetary payments (education and health facilities) can avoid large losses to the poor.

- Improvements to livelihoods of the poor through clean-up and ecosystem restoration.

- Increase in food security from higher productivity from sustainable farming and ecosystems through access to knowledge and technology.

- Increase in health and education indicators through social investment projects.

- Increase access to alternative and clean energy supplies.

While the relevance of CRES to poverty reduction and well-being is clear, nevertheless there are some critical enabling factors that determine whether the poor will be able to access these options. Key enabling factors for the poor include:

- Are the rights to compensation, especially for the poor, defined? Are these rights tradable?

- Even where rights exist, do the poor and marginal groups have access to and knowledge of compensation mechanisms?

- Do the poor have rights over land and can thus participate in reward schemes?

- Are the poor able to access financial capital to make investments for reward schemes?

- Do the poor bear opportunity costs as a result of reward schemes, and are the poor in the position to access rewards?

- Can rewards be in the form of community level investments on health, education and infrastructure that benefit the poor? 

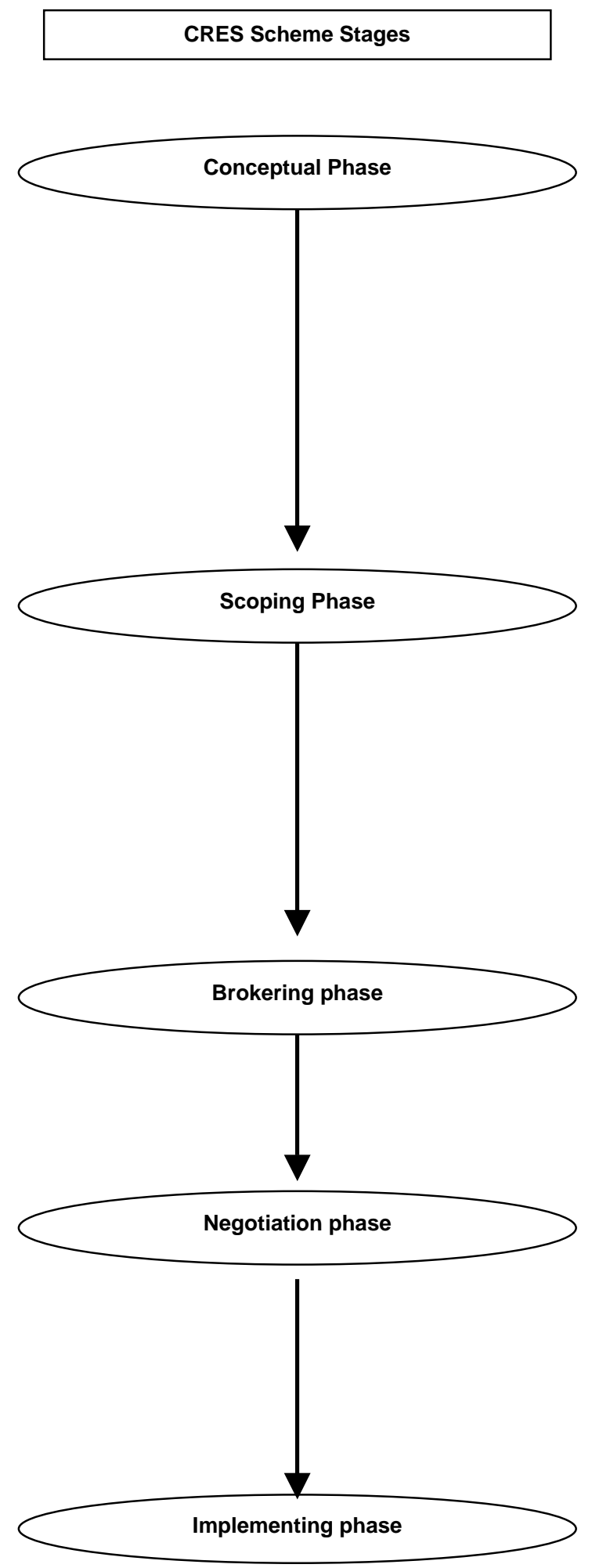

Fiqure 7: Relationship between CRES and Pro-poor
Pro-poor and Well-being Considerations

\section{Preliminary Assessment}

Who are the poor and how is poverty defined?

- What is the ecosystem service in question and are there a large number of poor believed to reside at the select site and have a direct relationship with the provision of the service (providers and beneficiaries)?

Baseline Scenario Assessments

What is the baseline land and resource use and the link to the ecosystem service in question?

Who are the providers and who are the beneficiaries?

- Do the poor actually influence the provision of the ecosystem service? By how much?

- Do the poor actually benefit from the provision of ecosystem service? By how much?

\section{CRES Alternative Scenario Assessments}

- What are the changes to land and resource use and link to the ecosystem service in question as the basis for CRES alternative scenario?

- Will the poor potentially benefit as providers and/or beneficiaries in changes to land and resource use? If not, what are the ways in which the poor will potentially lose from changes in land and resource use (access to ecosystem services, employment, higher prices, etc))?

Providers and Beneficiaries Assessment

- Are all the providers, including the poor, of the ecosystem service under CRES identified?

- $\quad$ Are all the beneficiaries, including the poor, of the ecosystem service under CRES identified?

Reward/Compensation Assessment

What are the actual rewards defined and agreed for the providers and do they include the poor providers?

- If the poor are not providers, is there as way to compensate the impacts they may incur through the type of rewards agreed?

- If the poor are beneficiaries, will they benefit from better access and incur impacts from rewards?

Implementation Assessment

- What is the mode of transferring rewards and do they reach the poor providers?

- If rewards are non-monetary community-based, do they actually benefit the poor?

- $\quad$ Are the poor compensated for impacts and do these compensation payments reach them?

- Are the poor beneficiaries given appropriate consideration in access and payments?

At the same time, it is also possible to consider the steps/stages involved in the design and implementation of CRES schemes, and these provide some clear avenues on how CRES can be made more pro-poor. By undertaking this exercise, it is possible to look at the different stages of CRES 
options design and implementation (see figure 7), and assess where CRES options can emphasize propoor elements at each stage. Namely that under:

\section{- Conceptual Phase:}

- Who are the poor and how is poverty defined? This allows for the identification of the poor households that fall in the jurisdiction of a select site.

- Whether there are a large number of poor believed to reside at the select site and have a direct relationship with the provision of the service (both as providers and beneficiaries)? This allows for the possible relationships between the poor and the provision of ecosystem services that can be tested at later stages.

\section{- Scoping Phase:}

- Are the poor providers ... do they actually influence the provision of the ecosystem service? By how much? This allows for the assessment of the nature of the poor households as providers of ecosystem services through land and resource use, and the influence of this on the ecosystem service in question under a baseline scenario.

- Do the poor actually benefit from the provision of an ecosystem service? By how much? This allows for the assessment of the nature of the poor households use of ecosystem services as beneficiaries under a baseline scenario. Compensation could be one option when benefits are impacted.

- What are the changes to land and resource use and link to the ecosystem service in question as the basis for CRES alternative scenario? This allows for the assessment of the extent to which the provision of ecosystem service(s) will be impacted by plausible land use changes or actual increase in pollution and damage.

- Will the poor potentially benefit as providers and/or beneficiaries in changes to land and resource use? This allows for an identification of how the poor fare under alternative scenarios, and thus allows the often undetected poor to be included in CRES options.

- If not, what are the ways in which the poor will potentially lose from changes in land and resource use (access to ecosystem services, employment, higher prices, etc))? This allows the assessment of costs imposed on the poor and thus potential compensation and rewards to offset costs.

\section{- Brokering Phase:}

- Are all the providers, including the poor, of the ecosystem service under CRES identified?

- Are all the beneficiaries, including the poor, of the ecosystem service under CRES identified? This allows for the assurance that the poor are included in the brokering phase both as providers and beneficiaries. Under the brokering phase the main objective is to bring the potential buyers and sellers together and to gain further insight as to the potential of reaching a RES agreement. A similar arrangement on CES can be undertaken in the brokering phase.

\section{- Negotiation Phase}

- What are the actual rewards defined and agreed for the providers and do they include the poor providers?

- If the poor are not providers, is there as way to compensate the impacts they may incur through the type of rewards agreed?

- If the poor are beneficiaries, will they benefit from better access from rewards?

During the negotiation phase actual rewards for ecosystem services providers or actual compensation for affected parties (ecosystem services beneficiaries) are defined. In this 
phase, intermediary actors have an important role to play in facilitating negotiations between the providers, beneficiaries and affected parties, and in the decision on the form of the reward/compensation and transfer mechanism. In this phase, intermediary actors can play a vital role in facilitating access to negotiations on the form of reward/compensation that positively impacts on the well-being of the poor. Finally intermediary actors can have an instrumental role to play in the negotiation phase in which the poor beneficiaries of ecosystem services who pay for these benefit are given a fair level of payment and negotiate appropriate and continued supply of the service.

\section{- Implementation Phase}

- What is the mode of transferring rewards and do they reach the poor providers?

- If rewards are non-monetary community-based, do they actually benefit the poor?

- Are the poor compensated for impacts and do these compensation payments reach them? In the implementation phase, the key concern is that the poor do actually receive the reward/compensation through the mode of transfer established. In case the rewards are non-monetary community-based, the role of intermediary actors may be to foster equitable sharing of rewards. Intermediary actors could have a potentially important role to play in ensuring that the poor are included and are actually compensated for the damages to their well-being.

In conclusion, this section highlights the practical relevance of CRES to poverty reduction and wellbeing of the poor. In particular, the section demonstrates that the relationship of CRES instruments to poverty reduction and well-being can be both positive and negative and manifest in multi-dimensions. The section also demonstrates when and where CRES instruments are relevant for poverty reduction at each stage of the design of CRES instruments. In essence CRES instruments can be pro-poor but these need to be carefully conceptualized, assessed and designed, and implemented and monitored. Many of these issues are further investigated in the rest of the issue papers in this series (ICRAF Working Papers 37, 38, 39, 40). 


\section{References}

Bohle HG, Downing TE and Watts MJ. 1994. Climate change and social vulnerability: toward a sociology and geography of food insecurity. Global Environmental Change, 4(1), 37-48.

Cavendish W. 2000 Empirical Regularities in the Poverty-Environment Relationship of Rural Households: Evidence from Zimbabwe. World Development 28(11), 1979-2003.

Chambers R. 1989. Vulnerability, coping and policy. IDS Bulletin 20(2): 1-8.

Clisby S. 1995. Population and the environment: gender, poverty and household-level analysis, Journal of Gender Studies 4:2 189-192.

Dasgupta P. 2003 An Enquiry into Destitution and Well-Being, Oxford: Oxford University Press.

DFID. 1999. Sustainable Livelihoods Guidance Sheets, Section 2 The Livelihoods Framework. Department for International Development, UK.

Duraiappah AK and Abraham A. 2004. Ecological Surety and Capabilities: Normative Issues 4th International Conference on the Capability Approach: Enhancing Human Security 5-7 September 2004, University of Pavia, Italy.

Emerton L and Bos E. eds. 2004. VALUE - Counting ecosystems as water infrastructure. Gland, Switzerland: The World Conservation Union (IUCN).

Grieg-Gran M and Bann C. 2003. A closer look at payments and markets for environmental services, in Gutman P. ed. From goodwill to payments of environmental services, a survey of financing options for sustainable natural resource management in developing countries. WWF MPO.

Jodha N. 1986. Common Property Resources and Rural Poor in Dry Regions of India. Economic and Political Weekly 21(27):1169-1181.

Kabeer N. 1991. Gender, Production and Wellbeing: retbinking the household economy Discussion Paper 288. Brighton: Institute of Development Studies, University of Sussex

Kabeer, N. 1994. Reversed realities: gender hierarchies in development thought. London: Verso

Landell-Mills N and Porras TI. 2002. Silver bullet or fools' gold? A global review of markets for forest environmental services and their impact on the poor. Instruments for sustainable private sector forestry series. London: International Institute for Environment and Development.

Malabed J, Velasquez J, and Shende R. Eds. 2002: Inter-linkages between the Ozone and Climate Change Conventions: Part 1 - Interlinkages between the Montreal and Kyoto Protocols. UN University, 53-70, Jingumae 5-chome, Shibuya-ku, Tokyo 150-8925, Japan; tel: 81-3-3499-2811;

Mayrand K and Paquin M. 2004. Payments for Environmental Services: A Survey and Assesment of Current Schemes. Unisfera International Centre for the Commission of Environmental Cooperation of North America, Montreal, p.9

Millennium Ecosystem Assessment. 2003. Ecosystems and Human Wellbeing: A Framework for Assessment. Washington, DC: Island Press.

Millennium Ecosystem Assessment 2005. Ecosystems and Human Well-being: Synthesis. Washington D.C.: Island Press. (http://www.maweb.org/en/products.aspx)

Miranda M, Porres I and Luz Moreno M. 2003. The social impacts of payments for environmental services in Costa Rica. London: International Institute for Environment and Development.

Pagiola S, Arcenas A and Platais G. 2005. Can payments for environmental services help reduce poverty? An exploration of the issues and the evidence to date. World Development 33:(2):237-253. 
Pagiola S and Platais G. 2003. Implementing Systems of Payments for Environmental Services: Initial Lessons of Experience. Paper presented at the Workshop on Ecosystem Services in the Tropics: Challenges to Marketing Forest Function, Spring 2003 Meeting of the International Society of Tropical Foresters, Yale University, April 5-6, 2003.

Poats SV. 2007. Report on the Latin American Regional Workshop on Compensation for Environmental Services and Poverty Alleviation in Latin America, April 26 - 28, 2006, Quito, Ecuador. ICRAF Working Paper no. 33. Nairobi, Kenya: World Agroforestry Centre.

Rojas, C. A., 1999. Evaluation of a Multifaceted Intervention to Prevent the Transmission of American Cutaneous Leishmaniasis in Colombia. Ph.D. Thesis, Chapel Hill: Department of Epidemiology, School of Public Health, University of North Carolina.

Sen A. 1979. Issues in the Measurement of Poverty. Scandinavian Journal of Economics 81: 285-307.

Sen A. 1985. Commodities and Capabilities. Oxford: Oxford University Press.

Sheer and Smith. 2000. Opportunities under the Clean Development Mechanism: Notes from CIFOR Bellagio Meeting Feb. 2000

Streeten P, Shahid Javed Burki, Mahbub ul Haq, Hicks N and Stewart F. First Things First: Meeting Basic Needs in the Developing Countries. New York: Oxford University Press, 1981.

Tognetti et. al. 2003. Assessing the Effectiveness of Payment Arrangements for Watershed Ecosystem Services (PWES). For Presentation at the Third Latin American Congress on Watershed Management, Regional Forum on Payments for Environmental Services.

Tognetti et. al. (undated). A Knowledge and Assessment Guide to Support the Development of Payment Arrangements for Watershed Ecosystem Services (PWES). Prepared for The World Bank Environment Department with support from the Bank-Netherlands Watershed Partnership Program

UNDP, 1997. Human Development Report. New York: United Nations Development Programme (UNDP).

UNEP 2002. Global Environmental Outlook 3. Nairobi: UNEP.

UNDP, 2004. Human Development Report. New York: UNDP.

UNEP 2006. Protecting coastal and marine environments from land-based activities: A guide for national action. Nairobi: UNEP.

World Bank 2005. World Development Report (WDR) 2000/2001: Attacking Poverty. World Bank: Washington.

WRI. 2002. The Wealth of the Poor. World Resources Institute. 


\section{Annex 1. Indicative list of ecosystem services}

\begin{tabular}{|c|c|c|c|}
\hline $\begin{array}{l}\text { Regulating services: responsible for } \\
\text { maintaining natural processes and } \\
\text { dynamics }\end{array}$ & $\begin{array}{l}\text { Provisioning services: } \\
\text { harvestable goods }\end{array}$ & $\begin{array}{l}\text { Cultural services providing a } \\
\text { source nonmaterial benefits }\end{array}$ & $\begin{array}{l}\text { Supporting services } \\
\text { necessary for the } \\
\text { production of all other } \\
\text { ecosystem services }\end{array}$ \\
\hline $\begin{array}{l}\text { Biodiversity related regulating services } \\
\text { - maintenance of genetic, species and } \\
\text { - maintenance of ecosystem structure } \\
\text { - maintenance of key ecosystem } \\
\text { processes for creating or maintaining } \\
\text { biodiversity }\end{array}$ & $\begin{array}{l}\text { Natural production } \\
\text { - } \text { timber } \\
\text { - } \text { firewood } \\
\text { - } \text { grasses } \\
\text { - } \text { fodder \& manure } \\
\text { - } \text { harvestable peat } \\
\text { - } \text { secondary (minor) } \\
\text { products } \\
\text { - } \text { harvestable bush meat } \\
\text { - } \text { fish and shellfish } \\
\text { - } \text { drinking water supply } \\
\text { irrigation and industry } \\
\text { - } \quad \text { water supply for } \\
\text { hydroelectricity } \\
\text { - } \text { supply of surface water } \\
\text { for other landscapes } \\
\text { - } \text { supply of groundwater for } \\
\text { other landscapes } \\
\text { genetic material }\end{array}$ & 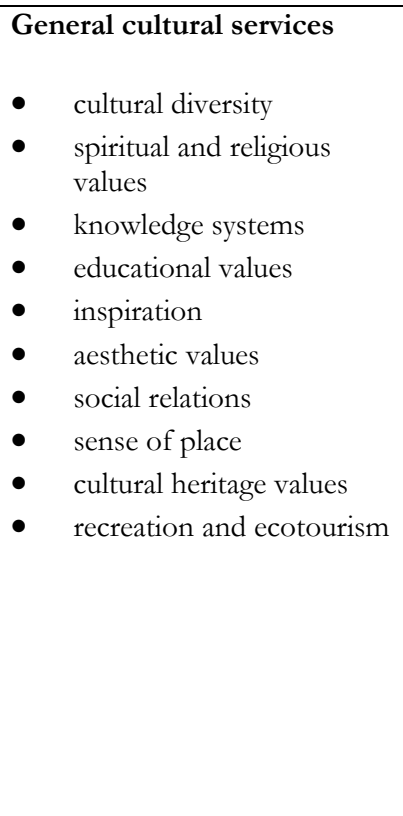 & $\begin{array}{l}\text { General supporting } \\
\text { services } \\
\text { - } \quad \text { soil formation } \\
\text { - } \quad \text { nutrients cycling } \\
\text { - } \quad \text { primary production } \\
\text { - } \\
\text { evolutionary processes }\end{array}$ \\
\hline 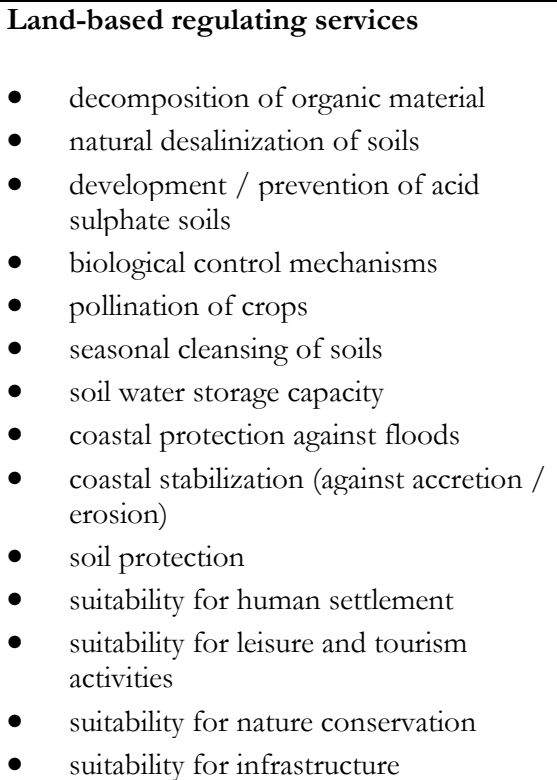 & 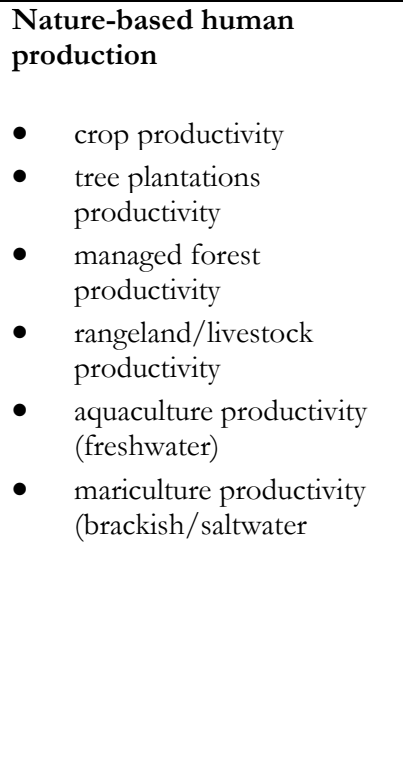 & & \\
\hline
\end{tabular}




\begin{tabular}{|c|c|c|c|}
\hline $\begin{array}{l}\text { Regulating services: responsible for } \\
\text { maintaining natural processes and } \\
\text { dynamics }\end{array}$ & $\begin{array}{l}\text { Provisioning services: } \\
\text { harvestable goods }\end{array}$ & $\begin{array}{l}\text { Cultural services providing a } \\
\text { source nonmaterial benefits }\end{array}$ & $\begin{array}{l}\text { Supporting services } \\
\text { necessary for the } \\
\text { production of all other } \\
\text { ecosystem services }\end{array}$ \\
\hline 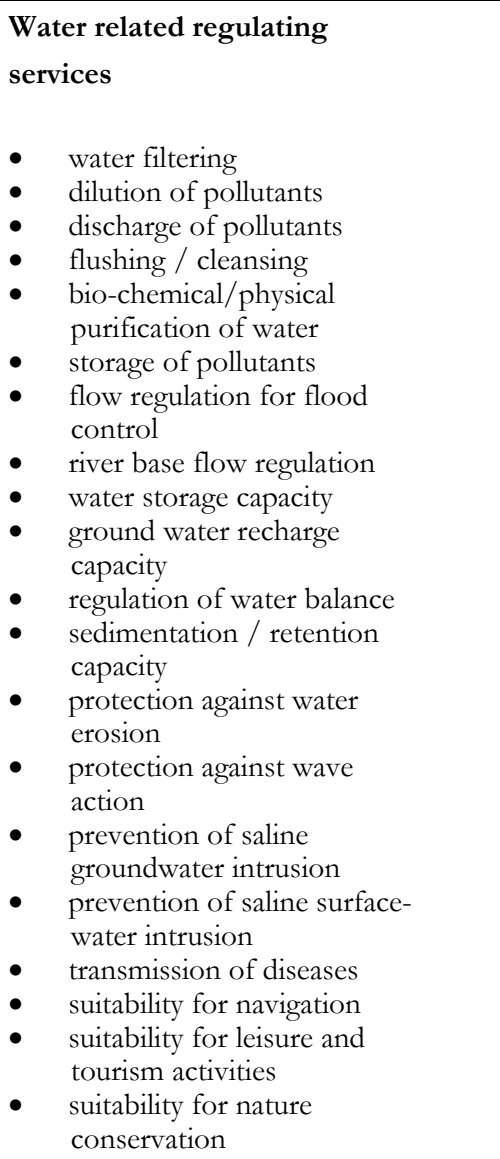 & & & \\
\hline $\begin{array}{l}\text { Air-related regulating services } \\
\text { - filtering of air } \\
\text { - carry off by air to other areas } \\
\text { photo-chemical air } \\
\text { processing (smog) } \\
\text { - trind breaks } \\
\text { - carbonission of diseases } \\
\text { sequestration }\end{array}$ & & & \\
\hline
\end{tabular}




\section{ICRAF Working Papers}

\section{5-2006}

1. Agroforestry in the drylands of eastern Africa: a call to action

2. Biodiversity conservation through agroforestry: managing tree species diversity within a network of community-based, nongovernmental, governmental and research organizations in western Kenya.

3. Invasion of prosopis juliflora and local livelihoods: Case study from the Lake Baringo area of Kenya

4. Leadership for change in Farmers Organizations: Training report: Ridar Hotel, Kampala, 29th March to 2nd April 2005

5. Domestication des espèces agroforestières au Sahel : situation actuelle et perspectives

6. Relevé des données de biodiversité ligneuse: Manuel du projet biodiversité des parcs agroforestiers au Sahel

7. Improved Land Management in the Lake Victoria Basin: TransVic Project’s Draft Report

8. Livelihood capital, strategies and outcomes in the Taita hills of Kenya

9. Les espèces ligneuses et leurs usages: Les préférences des paysans dans le Cercle de Ségou, au Mali

10. La biodiversité des espèces ligneuses: Diversité arborée et unités de gestion du terroir dans le Cercle de Ségou, au Mali

11. Bird diversity and land use on the slopes of Mt. Kilimanjaro and the adjacent plains, Tanzania

12. Water, women and local social organization in the Western Kenya Highlands

13. Highlights of ongoing research of the World Agroforestry Centre in Indonesia

14. Prospects of adoption of tree-based systems in a rural landscape and its likely impacts on carbon stocks and farmers' welfare: the FALLOW Model Application in Muara Sungkai, Lampung, Sumatra, in a 'Clean Development Mechanism' context

15. Equipping Integrated Natural Resource Managers for Healthy Agroforestry Landscapes.

16. Are they competing or compensating on farm? Status of indigenous and exotic tree species in a wide range of agro-ecological zones of Eastern and Central Kenya, surrounding Mt. Kenya.

17. Agro-biodiversity and CGIAR tree and forest science: approaches and examples from Sumatra

18. Improving land management in eastern and southern Africa: A review of polices.

19. Farm and Household Economic Study of Kecamatan Nanggung, Kabupaten Bogor, Indonesia: A Socioeconomic base line study of Agroforestry Innovations and Livelihood Enhancement

20. Lessons from eastern Africa's unsustainable charcoal business.

21. Evolution of RELMA's approaches to land management: Lessons from two decades of research and development in eastern and southern Africa

22. Participatory watershed management: Lessons from RELMA's work with farmers in eastern Africa.

23. Strengthening farmers' organizations: The experience of RELMA and ULAMP.

24. Promoting rainwater harvesting in eastern and southern Africa.

25. The role of livestock in integrated land management.

26. Status of carbon sequestration projects in Africa: Potential benefits and challenges to scaling up.

27. Social and Environmental Trade-Offs in Tree Species Selection: A Methodology for Identifying Niche Incompatibilities in Agroforestry [Appears as AHI Working Paper no. 9]

28. Managing Trade-Offs in Agroforestry: From Conflict to Collaboration in Natural Resource Management. [Appears as AHI Working Paper no. 10]

29. Essai d'analyse de la prise en compte des systemes agroforestiers pa les legislations forestieres au Sahel: Cas du Burkina Faso, du Mali, du Niger et du Senegal. 
30. Etat de la Recherche Agroforestière au Rwanda Etude bibliographique, période 1987-2003.

31. Science and Technological Innovations for Improving Soil fertility and Management in Africa.

32. Compensation and Rewards for Environmental Services in the Developing World: Framing Pan-Tropical Analysis and Comparison.

33. Report on the Latin American Regional Workshop on Compensation for Environmental Services and Poverty Alleviation in Latin America.

34. Asia Regional Workshop on Compensation for Ecosystems Services. A Component of the Global Scoping Study on Compensation for Ecosystem Services.

35. African Regional Workshop on Compensation for Ecosystem Services (CES)

36. Exploring the Inter-Linkages among and between Compensation and Rewards for Ecosystem Services (CRES) and Human Well-Being: CES Scoping Study Issue Paper no. 1.

37. Criteria And Indicators for Environmental Service Compensation and Reward Mechanisms: Realistic, Voluntary, Conditional and Pro-Poor: CES Scoping Study Issue Paper no. 2.

38. The Conditions for Effective Mechanisms of Compensation and Rewards for Environmental Services (CRES): CES Scoping Study Issue Paper no. 3.

39. Organization and Governance for Fostering Pro-poor Compensation for Environmental Services: CES Scoping Study Issue Paper no. 4

40. How important will different types of Compensation and Reward Mechanisms be in shaping poverty \& ecosystem services across Africa, Asia \& Latin America over the next two decades? CES Scoping Study Issue Paper no. 5. 


\section{Who we are}

The World Agroforestry Centre is the international leader in the science and practice of integrating 'working trees' on small farms and in rural landscapes. We have invigorated the ancient practice of growing trees on farms, using innovative science for development to transform lives and landscapes.

\section{Our vision}

Our Vision is an 'Agroforestry Transformation' in the developing world resulting in a massive increase in the use of working trees on working landscapes by smallholder rural households that helps ensure security in food, nutrition, income, health, shelter and energy and a regenerated environment.

\section{Our mission}

Our mission is to advance the science and practice of agroforestry to help realize an 'Agroforestry Transformation' throughout the developing world.
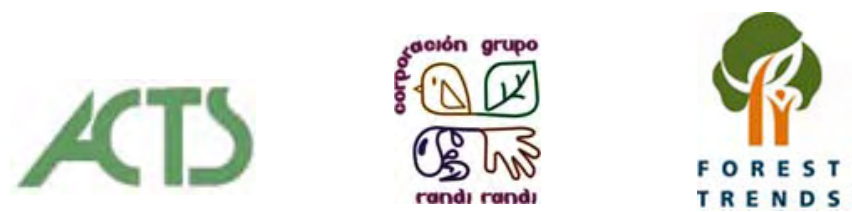

The World Conservation Union
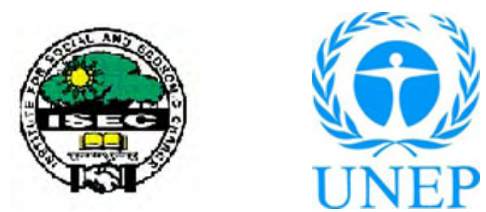

\section{IDRC * CRDI}

International Development

Centre de rechenches pour le

Research Centre

developpenent intereational

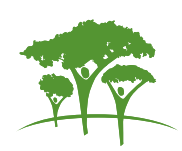

United Nations Avenue, Gigiri - PO Box 30677 - 00100 Nairobi, Kenya

Tel: +254207224000 or via USA +1 6508336645

Fax: +254207224001 or via USA +1 6508336646

www.worldagroforestry.org 